Schweikardt, C., Verheij, R.A., Donker, G.A., Coppieters, Y. The historical development of the Dutch Sentinel General Practice Network from a paper based into a digital primary care monitoring system. Journal of Public Health: 2016, 24(6), 545-562

\begin{tabular}{|l|l|}
\hline $\begin{array}{l}\text { Postprint } \\
\text { Version }\end{array}$ & 1.0 \\
\hline Journal website & http://link.springer.com/article/10.1007\%2Fs10389-016-0753-4 \\
\hline Pubmed link & \\
\hline DOI & $10.1007 / \mathrm{s} 10389-016-0753-4$ \\
\hline
\end{tabular}

This is a NIVEL certified Post Print, more info at http://www.nivel.eu

\title{
The historical development of the Dutch Sentinel General Practice Network from a paper-based into a digital primary care monitoring system
}

\author{
Christoph Schweikardt, Robert A. VerheiJ, GÉ A. DONKer, YVes Coppieters
}

\begin{abstract}
Aim: The Dutch Sentinel General Practice Network (SGPN) was founded in 1970 for disease surveillance in primary care, based on paper questionnaires. Advances in information technology offered new prospects of data collection from electronic health records (EHRs). This study investigates the resulting challenges for the SGPN and its transition towards electronic data collection.

Methods: A qualitative approach included triangulation of SGPN annual reports, network publications, its computerisation project protocol of 2004, public health policy documents, and expert interviews.

Results: In the 1990s, the design of the SGPN, coordinated by the research institute NIVEL, no longer corresponded to new Dutch government information demands regarding developments in primary care utilisation and quality. The emergence of the EHR-based Netherlands Information Network of General Practice (LINH) could have rendered the SGPN obsolete. However, NIVEL researchers recognised that routine EHR data on health problems could not fully provide required information obtained by questionnaires and samples for laboratory analysis. They developed a plan (1) taking EHR-based routine data collection as a basis, and (2) simultaneously retaining the more detailed supplementary data collection that was the core of the SGPN. The transition towards electronic data collection from 2005 onwards was followed by the integration of both networks into the NIVEL Primary Care Database in 2014.

Conclusion: The Dutch model is an example of a process responding to the challenges and opportunities associated with the emergence of electronic data collection, leading towards the integration of routine and supplementary data collection for both sentinel surveillance and health services research.
\end{abstract}

\section{INTRODUCTION}

A sentinel general practice (GP) network —or sentinel network of general practitioners (GPs) - “can be defined as a system that keeps a watchful eye on a sample of the population by supplying regular and standardized reports on the 
Schweikardt, C., Verheij, R.A., Donker, G.A., Coppieters, Y. The historical development of the Dutch Sentinel General Practice Network from a paper based into a digital primary care monitoring system. Journal of Public Health: 2016, 24(6), 545-562

incidence and the main epidemiological characteristics of specific diseases and of procedures in primary health care" (Van Casteren 1993, p. 253). Sentinel networks are well known for providing early warning of communicable diseases such as influenza and monitoring them over time (Fleming et al. 2003; Fleming 1998). Sentinel GP networks have developed in several industrialized countries since the 1960s. Today, sentinel GP networks surveying influenza exist in the majority of European Union (EU) member states (Valenciano et al. 2008; European Centre for Disease Prevention and Control (ECDC): Influenza surveillance. Sentinel surveillance). Some of the early GP networks in Europe simultaneously investigated several diseases or conditions in general practice (Deckers et al. 2006), notably the Weekly Returns Service (WRS) for England and Wales, operational since 1967 (Fleming 1999; Thomas et al. 2001), and the Dutch Sentinel General Practice Network, founded in 1970 (Bartelds et al. 1989). Other countries followed such as Belgium in 1979 (Van Casteren 2009), Switzerland in 1986 (Sentinella (n.d.) Themenübersicht Allgemeinpraktiker), Portugal in 1989 (National Health Institute Doutor Ricardo Jorge (INSA) (n.d.) Rede Médicos Sentinela) as well as regional Spanish sentinel GP networks from 1989 onwards (Vega Alonso et al. 2006, p. 497). Most of these networks included influenza surveillance at foundation or shortly thereafter.

Originally, the early network foundations such as the English, Dutch and Belgian sentinel networks relied on paper-based data collection by GPs. Since the 1980s, emergent information and communication technology (ICT) has provided new opportunities for data collection in primary care. In 1984, the French National Institute of Health and Medical Research (INSERM) established a computerised sentinel GP network, targeted at specific frequent infectious diseases in primary care and requesting GPs to connect to a central server for data entry (Flahault and Valleron 1997). In 1991, the WRS coordinator anticipated exciting prospects in the coming decade, because the "computerised record with its comprehensive coverage of both morbidity and prescribing" brought "a new dimension to epidemiological survey" (Fleming 1991, p. 183). During the 1990s, the WRS developed into a fully computerised collection system for data on routine diagnoses and episode types in general practice, based on data extraction from electronic health records (EHRs; Fleming 1999; The Royal College 2002).

Underlining the importance of the specific health care context, Griffiths and colleagues stated the following: "Each network develops in a particular time and place, with all the past experiences of the health service and its health care professionals influencing its development. It will also be influenced by research policy and resources, and the activity of other research institutions" (Griffiths et al. 2000, p. 914). The transition of the Dutch Sentinel GP Network towards computerised data collection displayed a distinctive feature: it was connected with the simultaneous integration into an existing EHR-based network. In this regard, this case study investigates the characteristics of the Dutch situation leading to the specific transition of the Dutch Sentinel GP Network towards computerisation. It aims to (1) track important decisions made during its foundation history which set the course for its further development, (2) analyse the consequences of Dutch health care policy in the 1990s for the development of the sentinel network, (3) show the subsequent strategies for transition towards electronic data collection, (4) describe the specific features of the resulting network structure, and finally, (5) discuss the 
Schweikardt, C., Verheij, R.A., Donker, G.A., Coppieters, Y. The historical development of the Dutch Sentinel General Practice Network from a paper based into a digital primary care monitoring system. Journal of Public Health: 2016, 24(6), 545-562

specific characteristics of the Dutch experience in comparison with those in other selected European countries - countries, in which national/major regional GP networks not exclusively devoted to influenza surveillance were also founded (Belgium, France, Portugal, Spain, Switzerland, and the United Kingdom).

\section{METHODS}

The development of the Dutch Sentinel GP Network was traced in six steps. First, the network foundation history was explored with regard to the determination of the network mission, organisation, and structure, taking into account the positions of the Undersecretary of Health and the first directors of the Netherlands Institute of General Practice (NHI) by consulting the first annual reports of the network, articles in "Medisch Contact" and the "Nederlands Tijdschrift voor Geneeskunde", together with the autobiographical history of the first NHI director (Van Es 2006).

Second, the functioning of the network and its research design prior to the 1990s were explored by consulting the annual reports as well as publications by the first two project leaders. Also, an expert interview (expert 1) was conducted with the second project leader (in office 1976-1985) by the first author.

Third, the consequences of Dutch health policy changes in the late 1980s and the 1990s for GP network surveillance were explored. Documents of the periods 19861987 through 2004-2005, published by the Second Chamber of Parliament (House of Representatives), were consulted regarding appraisals and the future of the sentinel network and/or the second national GP network LINH (Netherlands Information Network of General Practice). These documents are available online under "www.statengeneraaldigitaal.nl" and "www.officielebekendmakingen.nl". For the document search, the keywords "peilstation", "peilstations", "morbiditeitsregistratie", "Landelijk Informatie Netwerk", and "LINH" were employed. Information on LINH was also gathered from the LINH project report and subsequent annual reports.

Fourth, activities of the Sentinel GP Network in the 1990s and strategies to position it in adaptation to the new circumstances were identified via annual network reports from this period, publications of cooperation partners such as the National Institute for Public Health and the Environment (RIVM), an expert interview by the first author with the NIVEL GP project leader (expert 2), and the project proposal of 2004 which requested financial support from government for the transition.

Fifth, the transition towards computerisation is documented through annual network reports, information on the NIVEL homepage, and a NIVEL publication on the transition. For steps 4 and 5, an expert interview, supplemented by answers to written questions, was carried out by the first author with the third Sentinel GP project leader (in office 1985-2005; expert 3). Authorisation for all interview summaries in English was sought and obtained.

Sixth, in order to place the Dutch experience into a broader context, information provided by homepages, annual reports and research literature of other national/major regional research GP networks in Europe was explored, supplemented by a PubMed title/abstract search to identify other networks of this type (search words: "general practice" [Title/Abstract] together with the name of the respective country [Title/Abstract] and "database" [Title/Abstract]). 
Schweikardt, C., Verheij, R.A., Donker, G.A., Coppieters, Y. The historical development of the Dutch Sentinel General Practice Network from a paper based into a digital primary care monitoring system. Journal of Public Health: 2016, 24(6), 545-562

\section{The setting}

The Netherlands is one of those European countries, where general practice has a strong position in the health system, similar to England and Denmark (Wiegers et al. 2011, p. 7). In these countries, the GP acts as a gatekeeper who controls access to specialised medical care (Pedersen et al. 2012; Loudon 2008; Schellevis et al. 2005). In the Netherlands, "virtually all non-institutionalized Dutch citizens are registered with a GP so the total practice population represents the general population", and "doctor-defined health problems as presented to GPs in the Netherlands provide a valid profile of morbidity in the population" (Schellevis et al. 2005, p. 265). Thus, primary care research in the Netherlands is in a fortunate situation compared with other countries, where no mandatory patient list and referral system exist.

\section{Results}

The development of the Dutch Sentinel GP Network can be divided into three periods. The first period dates from its foundation until the end of the 1980s. The second period covers the 1990s and early 2000s, during which the future of the Sentinel GP Network was uncertain. During the third period, from 2005 onwards, an alignment of the Sentinel GP Network with LINH took place before both networks were integrated into the NIVEL Primary Care Database in 2014. The timeline is shown in Table 1.

\section{[TABLE 1]}

\section{Decisions of the foundation period which determined the future course of the network}

In 1965, professionalisation efforts of committed GPs and their professional organisation, the Dutch College of General Practitioners (NHG), led to the foundation of the Netherlands Institute of General Practice (NHI) in 1965 for GP research and training (Van Es 2006, pp. 43-58). Support came from the Ministry of Health, 1 which charged the NHI with the mission to provide information for government policy (Ministry of Health 1966, p. 164).

Another important actor of the foundation period was the Chief Medical Office of Health, which had been running sentinel practices since 1962 (Programme Committee Sentinel Practices 1971, p. 9). The resulting structure foresaw the NHI as the coordinating research institute and its director as chairperson of the Planning (later Counselling) Committee, with two Ministry of Health representatives and representatives from the foundation which had contributed to the formation of the $\mathrm{NHI}$ in the Planning Committee, as well as an officer from the Chief Medical Office of Health as the first project leader (Programme Committee Sentinel Practices 1971, p. 10).

Another strand of professionalisation of general practice was the foundation of chairs of general practice at Dutch universities in the late 1960s and 1970s, starting with Utrecht University in 1966 (Van Es 2006, pp. 70-71, pp. 82-83). By 1977, each university had its own chair of general practice (Crebolder and Stalman 2003). When the first director of the NHI became a professor at Utrecht University in 1966, he was charged with developing the Department of General Practice and the NHI simultaneously, so that his staff and tasks became interwoven across the two institutions (Van Es 2006, p. 127). When the NHI obtained separate management and new directors in 1971, the Sentinel GP Network did not become a university-based 
Schweikardt, C., Verheij, R.A., Donker, G.A., Coppieters, Y. The historical development of the Dutch Sentinel General Practice Network from a paper based into a digital primary care monitoring system. Journal of Public Health: 2016, 24(6), 545-562

network but remained part of the NHI (Van Es 2006, p. 92). According to the new NHI directors, the sentinel practice project was relevant for health policy, as well as other NHI activities, namely the creation and maintenance of a GP database - used for manpower planning (Groenewegen and Van der Zee 1979; Tweede Kamer 19841985, pp. 38-39) - and maintenance of a record of research in primary health care (Bol 1976, pp. 237-238). Furthermore, the universities were in charge of training future GPs and had taken over regional functions, while the NHI activities had a more nation-wide focus. Moreover, the university departments of general practice were part of the medical faculties, such that these university institutes were only very indirectly accessible to policy suggestions coming from the Ministry of Health (Bol 1976, pp. 237-238). The sentinel network thus remained attached to the NHI and, from 1985 onwards, to its successor NIVEL.

\section{Mission and characteristics of the Sentinel GP Network}

According to the Undersecretary (staatssecretaris) of Health, the original mission of the Sentinel GP Network was to explore the morbidity pattern in the Dutch population as far as it could be diagnosed in GP care, to signal diseases as well as shifts in disease patterns. The collected data could provide the backdrop for an analysis of disease phenomena and their causes, which, in turn, might lead to clues for a more speedy and effective health policy (Overeenkomst 1969).

The network was initiated with the ambition to be as representative of the general population as possible - with a nationally representative regional distribution and data collection in urban as well as rural areas - in order to obtain a representative picture of conditions seen in general practice. This principle has been retained to the present day (Programme Committee Sentinel Practices 1971, p. 12; Donker 2015, p. 16). To this end, it was necessary to report information on the practice populations (Programme Committee Sentinel Practices 1971, p. 10), with an update every 2-3 years (Programme Committee Sentinel Practices 1974, p. 10; Donker 2015, pp. 1619).

Questionnaires were completed by GPs on a weekly basis, sent to the NHI and, in the early days of the network, processed at the Chief Medical Office of Health (Programme Committee Sentinel Practices 1971, p. 13, p. 15). In order to advance the varying research topics, a "topic holder" approach was developed for a subset. The topic holder is the expert responsible for analysis of the collected data on a given research subject. The sentinel network must be informed about use, presentation and publication of the data (co-authorship) (Deckers and Schellevis 2004, Appendix B, pp. 118-119). The topic holder may be an NHI/NIVEL researcher but this is not mandatory. Aside from his/her expertise, the topic holder might also provide funding for analysis of the research topic. Thus far, the Sentinel GP Network has attracted topic holders from a broad variety of backgrounds, such as government and regional institutions, universities and private foundations.

The first project leader, simultaneously in charge of infectious diseases at the Chief Medical Office of Public Health from 1963 until 1988 (Geneeskundig inspecteur 1989), contributed a strong interest in infectious disease surveillance (Bartelds 1995, p. 5). From the beginning, influenza-like illness (ILI) was included, the only topic to be observed continuously up to the present day; however, the network did not limit itself to infectious diseases. Aside from ILI, the Sentinel GP Network weekly returns in 1989 included the observation of topics as diverse as cervical smears (continuously observed 1976-1998), sterilisation of men (1972-1999), sterilisation 
Schweikardt, C., Verheij, R.A., Donker, G.A., Coppieters, Y. The historical development of the Dutch Sentinel General Practice Network from a paper based into a digital primary care monitoring system. Journal of Public Health: 2016, 24(6), 545-562

of women (1974-1999), prescription of the morning-after pill (1972-1991), burns (1988-1989), suicide (attempts) (1979 to present), acute atypical headache (19881992), pregnancy despite contraception (1987-1991), outpatient mammography (1988-2000), consultations regarding concern about HIV/AIDS (1988 to present, from 2008 onwards as part of sexually transmitted infections), and referrals to a speech therapist (1989-19902) (Bartelds 1991, p. 18, p. 140; Donker 2015, pp. 167169).

In 1988, a project for the processing of sentinel network data by a working group of the Ministry of Health was successfully completed (Bensing 1988, p. VII). The Sentinel GP Network Counselling Committee recommended further pursuing the path towards computerisation but without impairing the functioning of the network (Bensing 1988, p. VII). In 1991, the NIVEL directors expressed the need to obtain computerised data from primary care and emphasized that few tools existed for the collection of longitudinal annual data. Indeed, the Sentinel GP Network did collect annual data, but "only relating to a limited number of auxiliary questions" (Bensing et al. 1991, p. 51, our translation). Computerised GP data collection had become part of a new government research agenda, but with a focus on procedures in general practice (as described in the following paragraph), while the Sentinel GP Network, with its epidemiological research design, could not satisfy this new priority.

\section{A new government research agenda since the 1980 s and its consequences}

Since the publication of the Policy Programme Health Care Structure in 1974, strengthening primary care in the Netherlands had been on the political agenda due to the expansion of more expensive secondary care (Boot and Knapen 2005, pp. 5354). Several documents from the early 1980s show government plans to extend primary care research. The Primary Health Care Outline 1979-1980 considered the extension of the NHI research programme to include activities such as methodology development, documentation, evaluation, needs assessment, recording systems, and experiments in primary care (Ministry of Health 1980, p. 42). In the Policy Programme Primary Care of 1983, the Ministry of Health dedicated a separate chapter to "research: situation and bottlenecks". It diagnosed a lack of research on the practice of primary health care, offer and demand, the care delivery process, and multidisciplinary cooperation between primary care facilities (Ministry of Health 1983, pp. 41-42). Subsequently, the Ministry of Health commissioned the first Dutch National Survey of Morbidity and Interventions in General Practice, which was carried out in 1987-1988 under the responsibility of NIVEL (Bensing et al. 1991, pp. 51-52). This study still relied on pen and paper data collection, but the plans of the Ministry of Health went in a different direction: the Ministry was engaged in supporting automation of GP practices as well as measures to improve the quality of care in general practice. In order to evaluate the latter, the Ministry of Health planned a GP information network - not only would regular production data (such as the number of procedures, referrals, prescriptions, and diagnostic requests) become available, it would also be related to the quality of care. Improving the quality of care could include the use of standards, impact assessment of standards and training, and the relationship between the complaint of the patient and the activities of the GP (Ministry of Health 1991, p. 146).

In the early 1990s, EHRs made it possible for the first time to collect data on a much larger scale than had been possible with paper forms. By the mid-1990s, an inventory counted 14 general practice registration networks in the Netherlands, of which 9 
Schweikardt, C., Verheij, R.A., Donker, G.A., Coppieters, Y. The historical development of the Dutch Sentinel General Practice Network from a paper based into a digital primary care monitoring system. Journal of Public Health: 2016, 24(6), 545-562

were computerised and 2 were in transition from paper forms to computer registration (Hart et al. 1999, pp. 173-174). EHR-based data collection in combination with quality of care improvement was a field in which NIVEL was by no means the only competitor. The Quality Research Working Group (WOK) from the Universities of Nijmegen and Maastricht which became an eminent research institution in the following decades and is known today as the Scientific Institute for Quality of Healthcare, IQ Healthcare for short (Van der Avoort et al. 2008;

Hoogleraar Richard Grol neemt afscheid 2011), was also eager to embrace the topic. The government commissioned NIVEL together with WOK to set up such an EHRbased GP network, the Netherlands Information Network of General Practice (LINH; De Bakker et al. 1997, p. 11). NIVEL was responsible for the overall functioning of the network, generating annual reports and maintaining the database, whereas WOK dealt with the data collection process and contacts with participating practices (Abrahamse et al. 1996, p. 24). The mission of LINH was to generate representative and continuous quantitative and qualitative information on the care provided by Dutch GPs (De Bakker et al. 2001, p. 9). LINH was set up in 1991 and obtained formal operational status in 1996 (De Bakker et al. 1997, p. 11, p. 43). GPs were instructed to combine each referral and prescription with the entry of a working diagnosis, in the form of an ICPC code (International Classification of Primary Care, an internationally recognised classification for registration in general practice (WHO (n.d.) International Classification of Primary Care); De Bakker et al. 1997, p. 12). Data were continually collected on (1) GP-patient contacts, (2) drug prescriptions with associated diagnosis, and (3) referrals with associated diagnosis. In addition, data were collected on specific topics in the field of quality of care (De Bakker et al. 2001, p. 9). LINH data quickly entered government policy documents. By 1994, LINH data on referrals to specialists, collected since March 1993 (De Bakker et al. 1997, p. 14), were already being used in the government planning document Financial Overview Care 1995 (Ministry of Health 1994, p. 271). In 1999, the Minister of Health took LINH as a model for the development of sentinel practices in physiotherapy and exercise therapy (Ministry of Health 1999, p. 64). Data collection from the LINH network also played an important role in the Second National Survey of Morbidity and Interventions in General Practice 2000-2002 (Schellevis et al. 2004, p.11, p. 123). Since 2002, LINH has also collected GP-patient contacts with an ICPC diagnosis. LINH thus changed "from a registration of procedures with associated morbidity into a registration of morbidity with associated procedures" (Tielens 2002, Voorwoord, our translation) in general practice.

\section{Uncertain future of the Sentinel GP Network in the 1990s}

While LINH routine data collection was extended, the future existence of the Sentinel GP Network became uncertain. The NIVEL director addressed the situation of the Sentinel GP Network publicly at the annual Sentinel GP Network meeting of 1994 (Bartelds 1995, p. 4). In the late 1990s, Ministry of Health officials had the impression that they were financing two networks which performed essentially the same tasks: they believed that either only one network was needed, or that the two networks could be merged (interview with expert 2).

During this period of insecurity, the Sentinel GP Network continued and extended its engagement in the following areas of expertise:

1. 
Schweikardt, C., Verheij, R.A., Donker, G.A., Coppieters, Y. The historical development of the Dutch Sentinel General Practice Network from a paper based into a digital primary care monitoring system. Journal of Public Health: 2016, 24(6), 545-562

The network provided additional material from the patient (urine samples, throat and nasal swabs, stool, etc.). The samples were sent to laboratories for further investigation into the cause of the infection. These additional diagnostic activities and the related questionnaires often went beyond the routine activities of a GP. From 1996 to 1999, the incidence of gastroenteritis in patients consulting sentinel network GPs and the role of several pathogens were studied (De Wit et al. 2001). This research was commissioned, among others, by the Health Care Inspectorate (part of the State Public Health Inspectorate; De Wit et al. 1999, p. 1).

2.

The network continued international cooperation among sentinel networks on influenza surveillance, which had commenced with participation in the Eurosentinel project 1988-1991 (Bartelds 1991, p. 2; Bartelds 1997, p. 2). European cooperation continued to develop and resulted in the European Influenza Surveillance Scheme (EISS) in 1996, which was coordinated by NIVEL. EISS became part of the European early warning and response system for communicable diseases, which was "officially launched on 1 January 2000" (European Influenza Surveillance Scheme 2001, pp. 9-10).

From the winter of 1992/1993 onwards, GPs sent random swabs from patients with influenza-like illness (ILI) symptoms to the RIVM, which diagnosed the ILI pathogen (Ministry of Health et al. 2004, p. 28). For monitoring of Chlamydia pneumoniae in the Netherlands, which was carried out during the winter seasons by the RIVM in the mid-1990s, the Sentinel GP Network was the only source (Heijnen and De Boer 1998, p. 251). According to the national plan on influenza in 2004, about $75 \%$ of sentinel GPs sent in 400-500 swabs during a typical influenza season (Ministry of Health 2004, p. 28). In the context of the nationwide Infectious Diseases Surveillance Information System, which was established in the course of the 1990s, the RIVM considered the sentinel practices as necessary to complement the microbiological laboratories, in particular for diseases which in the majority of cases did not lead to a consultation and diseases for which no laboratory diagnosis was necessary such as influenza and foodborne infections (Bartelds 1997, p. 5; Sprenger and Schrijnemakers 1998, p. 1925). The sentinel network favoured continued collaboration with the RIVM in the future as well (Bartelds 1999).

3.

At the turn of the century, NIVEL acted as the coordinator of two European GP network research projects, the "Health monitoring in sentinel practice networks" project (1998-2000; Fleming et al. 2003), and the "Health information from primary care" project (2001-2004; Deckers and Schellevis 2004). During the first project, the foundations for an Expert and Documentation Centre, "to which existing and new networks can look for advice and support in developing networks for monitoring morbidity in primary care", were established at NIVEL (Fleming et al. 2001, p. 1213). The WRS director, who served as advisor to the Dutch Sentinel GP Network from 1997 onwards (Bartelds 1998, p. 3), was involved as project coordinator for the first project (Fleming et al. 2001, p. 2) and as a WRS representative for the second project (Deckers and Schellevis 2004, p. 10).

4. 
Schweikardt, C., Verheij, R.A., Donker, G.A., Coppieters, Y. The historical development of the Dutch Sentinel General Practice Network from a paper based into a digital primary care monitoring system. Journal of Public Health: 2016, 24(6), 545-562

Furthermore, the Sentinel GP Network investigated the possible use of EHR data for the weekly returns, particularly with regard to which extent ICPC coding led to the same morbidity registration results. The network concluded that routine registration and ICPC classification were not suitable to obtain the type of information which was typically generated by the sentinel practices. Notably, providing supplementary information went beyond routine GP registration activities. Data on some topics such as making a cervical smear or requesting a mammography could also be derived from EHRs, as was done in LINH. In order to avoid double registration, improved cooperation with LINH was envisaged (Bartelds 1998, pp. 5-6).

The NIVEL GP project leader recalled that NIVEL positioned the Sentinel GP Network vis-à-vis the government as a network for special assignments to demonstrate the added value of the Sentinel GP Network: routine information, such as prevalence and incidence rates, could be derived from EHR data. This task had thus been taken over by LINH. However, the Sentinel GP Network remained necessary (1) for special questions beyond routine EHR registration, when nose, throat and/or urine samples were of interest and to be sent to the laboratory for further diagnosis of the pathogen; (2) in order to investigate the etiology of specific conditions such as sports injuries. A large number of diagnostic codes for fractures and injuries already existed, but from these it was not known whether they were related to sports. This constituted additional information which was not available from routine electronic health records; and (3) to investigate diseases or events, which were sensitive issues from a political or medical point of view, or both, such as suicide and euthanasia. The Ministry of Health accepted this argumentation (interview with expert 2). It even commissioned research on the management of unwanted pregnancies in general practice and the role of the GP from 2003 onwards (Tweede Kamer 2002, p. 3, Bartelds 2004, pp. 125-129). Data for that research were collected until 2011 (Donker 2014, p. 176); however, the Ministry of Health also made clear to the NIVEL directorate that an adjustment towards LINH had to be made (Bartelds 2003, p. 16).

\section{An integrated network: more than the sum of its parts-adjustment strategy towards LINH}

In 2004, NIVEL researchers in charge of the Sentinel GP Network and LINH submitted a proposal to the Ministry of Health to integrate the Sentinel GP Network into LINH. This proposal underlined the different profiles of the sentinel network and LINH (Verheij R, Bartelds A, De Bakker D, Schellevis F. Van Weekstaat tot HIS: Gezondheidsinformatie uit één geïntegreerd huisartsennetwerk [From paper based weekly reporting to EHR: Health information from an integrated GP network], 29.09.2004 [project protocol], pp. 2-3). In the sentinel network, morbidity would be registered by ICPC codes in the same manner as in LINH in the future (protocol, p. 8). In this way, the Sentinel GP Network would extend the LINH network data collection, allowing better precision and regional differentiation.

The core innovation proposed was the development of a module integrated into the EHR, so that data could be extracted weekly, not only half yearly as in LINH (protocol, pp. 8-9). By using ICPC codes for health problems, NIVEL aimed to diminish the double workload experienced by GPs who had to record data in their EHR systems as well as on paper forms as participants of the Sentinel GP Network. Information was now to be requested using replacement online forms. Furthermore, 
Schweikardt, C., Verheij, R.A., Donker, G.A., Coppieters, Y. The historical development of the Dutch Sentinel General Practice Network from a paper based into a digital primary care monitoring system. Journal of Public Health: 2016, 24(6), 545-562

ICPC codes entered routinely could be linked to a so-called "trigger" function integrated in the EHR system - when GPs entered ICPC codes which were related to a specific research question to be explored in depth, a pop-up screen with instructions such as requests to send a swab to the laboratory (protocol, p. 10), and/or questions related to the topics to be answered by the GP in order to identify a case was to appear. An example provided in the protocol (p. 10) was research on injuries by dog bites, with the pop-up triggered by the entry of ICPC code A80 (trauma/injury, not otherwise specified). Thus, the GP could mark whether or not a dog bite was the cause of the injury and enter further information when this was the case. The protocol marked the transition of the sentinel practices towards EHR-based registration before week 40 of 2005, the start of the 2005/2006 influenza season (protocol, p. 11).

\section{Computerisation of the Sentinel GP Network and integration into the NIVEL Primary Care Database}

With the subsidy, the Sentinel GP Network proceeded towards a mixed data collection system between 2005 and 2009. The introduction of coding standards in the sentinel network meant that sentinel GPs were requested to record a symptom/health problem or diagnostic ICPC code for every patient contact in the EHR. These efforts paralleled those of the Dutch College of General Practitioners (Nederlands Huisartsen Genootschap) to advance comprehensive EHR recording among GPs in general.

The workgroup preparing the first set of guidelines on adequate EHR file creation, published in 2004, adopted the position that an ICPC code had to be provided for complaints, diseases, or disorders (Nederlands Huisartsen Genootschap 2004, p. 16). The project protocol had envisaged that a few of the sentinel practices might quit when requested to record morbidity completely in the EHR and would have to be replaced (protocol, p. 8). No pressure was put on practices to change software providers in case they did not work with the EHR software included in the project, and arrangements were made for practices wishing to continue using paper registration only. Despite these measures, implementation of the sentinel module in the practices went along with a major shift in GP participation. More than half of the 56 GPs from the 2004 sentinel network had left it by January 1, 2009 (Bartelds 2006, pp. 179-180; Donker 2011, pp. 163-164),3 whereas the turnover of GPs had been less than $5 \%$ per year at the beginning of the decade (Deckers and Schellevis 2004, Appendix B, p. 113).

For several weeks, GPs were requested to record both on paper and electronically, and the respective numbers were checked by the project leader. The project team discovered that the implementation of computerised registration required a tailored approach for each practice, and that the quality of paper registration deteriorated rapidly during parallel digital recording (Schellevis et al. 2009, pp. 19-20). By 2009, routine data collection in the Sentinel GP Network had been implemented with regard to four EHR software programmes and for other GPs via upload to a website (Schellevis et al. 2009, p. 19). Routine EHR data in 38 of 46 sentinel practices was collected digitally to the satisfaction of the participating GP (Schellevis et al. 2009, pp. 19-20). The collection of supplementary non-routine data on in-depth questions remained mainly paper based (Donker 2011, p. 5). In 2013, 10 of 13 weekly return research topics still required GPs to send paper questionnaires to NIVEL. These questionnaires were used in order to obtain information not routinely recorded in the 
Schweikardt, C., Verheij, R.A., Donker, G.A., Coppieters, Y. The historical development of the Dutch Sentinel General Practice Network from a paper based into a digital primary care monitoring system. Journal of Public Health: 2016, 24(6), 545-562

EHR (e.g., sexual and risk behaviour of patients with concerns about a sexually transmitted infection) or for which no suitable ICPC main code existed at all (e.g., symptoms caused by the oak processionary caterpillar) (NIVEL, Continue Morbiditeits Registratie, Peilstations Nederland: Toelichting op: Rubrieken 2013). In 2010 and 2012, NIVEL applied a data quality feedback tool to 92 voluntary LINH practices (Van der Bij et al. 2016), before, in 2014, both the Sentinel GP Network and LINH were integrated into the NIVEL Primary Care Database. NIVEL took over LINH coordination completely from IQ Healthcare and increased the number of contributing practices substantially. In 2014, the NIVEL Primary Care Database collected data from 433 general practices with over 1.7 million enrolled patients (Prins et al. 2015, p. 6), encompassing more than $10 \%$ of the Dutch population. The sentinel network was integrated as a particular set of practices willing to collect additional information beyond the data recorded in the EHR systems, but the number of practices can be extended if there is a need and budget. Since 1 January 2015, also all supplementary, previously paper-based, data in sentinel practices has been collected electronically via online questionnaires. Only specimens such as nose and throat swabs and urine are still sent by regular mail. The characteristics of the sentinel GP practices are shown in Table 2. External cooperation and proposals for new research topics are welcome.

\section{[TABLE 2]}

Furthermore, the NIVEL Primary Care Database has extended the monitoring of health and the utilisation of health services in a representative sample of the Dutch population to GP out-of-hours services and other primary health care professionals (primary care psychologists, physiotherapists, exercise therapists, dieticians, speech therapists, and pharmacists) (NIVEL (n.d.) NIVEL Zorgregistraties eerste lijn). Its data protection and pseudonymisation principles have already been described elsewhere (Kuchinke et al. 2016).

\section{DEVELOPMENT OF SENTINEL GP NETWORKS AND OTHER GP DATABASES IN SIX OTHER EUROPEAN COUNTRIES}

\section{Development of sentinel GP networks}

Regarding the development of sentinel GP networks in other European countries, a heterogeneous picture emerges. The computerised networks in England and France further developed their network. In the WRS, a database with patient-linked and pseudonymised data was introduced as of 2007 (Fleming 2011) and operational for influenza swabbing in 2011 (RCGP: Weekly Returns Service Annual Report 2011, p. 12). In 2015, the network, now under the name "Royal College of General Practitioners Research and Surveillance Centre" (RCGP RSC), commissioned a new data and analytics hub at the University of Surrey (Correa et al. 2016).

In the French Réseau Sentinelles, a web interface became the preferred mode of data collection in 1996, with a client module for the GP computer being developed by 2009 to widen choices for GPs regarding the mode of data reporting (Turbelin et al. 2010). In Portugal, the Médicos Sentinela network initiated computerisation shortly after the turn of the century. In 2002, the RIOS platform was created to facilitate sentinel and other network notification via Internet in addition to paper-based entries (National Health Institute Doutor Ricardo Jorge (INSA) (2008) Plataforma RIOS). 
Schweikardt, C., Verheij, R.A., Donker, G.A., Coppieters, Y. The historical development of the Dutch Sentinel General Practice Network from a paper based into a digital primary care monitoring system. Journal of Public Health: 2016, 24(6), 545-562

By 2003, a pilot project with Internet-based data collection had begun in the sentinel network (webpage, 2 GPs) (Deckers and Schellevis 2004, p. 128).

In Spain, GP sentinel networks developed regionally, notably the GP Sentinel Networks of Castile and Leon (operational in 1989), the Basque Country (1990), Madrid Community (1991), and Valencia Community (1995; Vega Alonso et al. 2006, p. 497), followed by other Spanish regions. In 1991, the Castile and Leon GP network opened up to paediatricians, and in 2006 to nursing staff, becoming the Health Sentinel Network of Castile and Leon (Junta de Castilla y León, Consejería de Sanidad (n.d.) ¿Qué es?). Based on a Royal Decree issued in 1995, a national epidemiological surveillance network was created in 1996, including integral influenza sentinel surveillance (Vega Alonso et al. 2006, p. 497). In the Health Sentinel Network of Castile and Leon, new influenza tracking software was introduced on GP computers in 2015 (Saludadiario.es (2015) En Castilla). In Belgium and Switzerland, paper forms have been retained at least as an option until recently (see Table 3 ).

\section{[TABLE 3]}

\section{Development of other GP networks}

The development of other GP networks was heterogeneous as well, with the United Kingdom as a forerunner in Europe. In England, several other GP research databases were founded, run by public health authorities, universities and/or commercial enterprises. Notable among these is the General Practice Research Database (GPRD), formerly the VAMP (Value Added Information Medical Products) Research Databank, established in 1987 (Independent Scientific Advisory Committee for Medicines and Healthcare products Regulatory Agency (MHRA) database research (ISAC) (n.d.) Annual Report 2012, p. 20). Since 2012, it has been known under the name of the Clinical Practice Research Datalink (CPRD) (Independent Scientific Advisory Committee for Medicines and Healthcare products Regulatory Agency MHRA database research ISAC (n.d.) Annual Report 2012, p. 3). Further examples include Qresearch, UK IMS Disease Analyzer and The Health Improvement Network (THIN) (Williams et al. 2012, p. 91); furthermore, research infrastructure was developed further into the United Kingdom Clinical Research Network (UKCRN) with a central role for primary care (Sullivan et al. 2007).

In France, the computerised Observatory of General Medicine (OMG) database was initiated by the French Society of General Practice in 1993 (De Pange 2004, p. 10). However, it did not survive due to a lack of resources and was closed in 2011 (Société Française de Médecine Générale (2012) L'avenir). The commercial Open Rome Observatory (Organize and Promote Epidemiological Network, Réseau d'Observation des Maladies et d'Epidémies), a creator of multidisciplinary networks involving caregivers and researchers in epidemiology, public health, risk management, and economic evaluation in health (Organize and Promote Epidemiological Network, Réseau d'Observation des Maladies et d'Epidémies (Open Rome) (n.d.) Bienvenue), does not target general practice specifically but has also been engaged in primary care initiatives such as the GROG (Regional Groups Influenza Observation) network since 1984 (Organize and Promote Epidemiological Network, Réseau d'Observation des Maladies et d'Epidémies (Open Rome) (2013) Réseau des GROG). The Permanent Epidemiological Observatory Thales, a commercial database which also includes other specialties, was set up in 1990 (Cash 
Schweikardt, C., Verheij, R.A., Donker, G.A., Coppieters, Y. The historical development of the Dutch Sentinel General Practice Network from a paper based into a digital primary care monitoring system. Journal of Public Health: 2016, 24(6), 545-562

(2000) THALES). Its coordinator also cooperates with the Italian GP network Health Search (Istituto di Ricerca della Società Italiana di Medicina Generale (SIMG) (n.d.) Health Search).

In Belgium, the EHR-based Flemish Intego general practitioner network, coordinated by the Academic Centre for General Practice at Leuven University, was set up in 1990 as the first computerised morbidity registration network in Belgium (Truyers et al. 2015, p. 9). In French-speaking Belgium, the Federation of Integrated Primary Health Care Centres (Fédération des maisons médicales et des collectifs de santé francophones) established the "tableau de bord" (monitoring chart), starting with a pilot project in 2004 (Carbonez 2010, pp. 4-5). The Belgian national Sentinel GP Network has remained paper-based so far (Van Casteren 2009, p. 10), but will organise its transition to computerised data collection in the context of the Federal Healthdata.be initiative in 2016/2017. Healthdata.be has begun to build a research infrastructure for-according to the Belgian Federal Minister of Health, preferably all-Belgian health databases (Scientific Institute of Public Health (WIV-ISP) (n.d.) Healthdata.be: une nouvelle plateforme).

In Spain, the General Practice Pharmacoepidemiologic Research Database (BIFAP) was founded in 2000 (Salvador Rosa et al. 2002), and contains information provided by GPs and paediatricians in the Spanish National Health Service (NIH National Cancer Institute (2013) Base de datos). In Catalonia, SIDIAP, the Information System for the Development of Primary Care Research, was founded in 2010 (SIDIAP Information System for the Improvement of Research in Primary Care (n.d.) Background). It is based on electronic medical records of about 5 million people from Catalonia, around $80 \%$ of the population in this region (Muñoz-Ortego et al. 2014, p. 1771).

In Switzerland, EHR-based data collection has also begun within Swiss primary care settings. Established in 2009 at the Institute of General Practice of the University of Zurich, the FIRE project (Family Medicine ICPC Research using Electronic Medical Records) (Universität Zürich, Hausarztmedizin - FIRE (n.d.) Das FIRE-Projekt) "provides the first and largest standardized collection of structured medical routine data from Swiss primary care" (Streit et al. 2015, p. 2). Regarding Portugal, where many obstacles to primary care research have been identified (Granja et al. 2014, p. 7), no other major GP network has been found.

\section{DISCUSSION}

\section{Foundation history and institutional context of Sentinel GP Network development}

The Sentinel GP Network owes much to three factors shaping the context of its development: (1) during its foundation period, a national GP research institute already existed, independent of the Dutch universities and before chairs of general practice were created there; (2) professionalisation efforts of committed GPs met government interests in the field of surveillance in primary care; and (3) from the beginning, government had a stake in the mission of this institute and the mission of the Sentinel GP Network, namely providing data for health policy planning. For a federal government eager to obtain such data, the NHI as the coordinating institution of the sentinel GP network was the more obvious choice than a university department. At the NHI, representation of the government in the 
Schweikardt, C., Verheij, R.A., Donker, G.A., Coppieters, Y. The historical development of the Dutch Sentinel General Practice Network from a paper based into a digital primary care monitoring system. Journal of Public Health: 2016, 24(6), 545-562

Planning/Counselling Committee provided the possibility to exert influence directly and to suggest research topics which were relevant in their eyes.

A Dutch peculiarity is the consecutive twofold involvement of two different institutions, first the Chief Medical Office of Health and the NHI in the foundation period, and then NIVEL as successor to the NHI and WOK for setting up LINH. Both times, NIH/NIVEL was in charge of the overall functioning of the network and ultimately remained the sole responsible institution. In England, where general practice has also had a strong position in the health system the whole time, the Royal College of General Practice remained in charge of the sentinel GP network. In other European countries, coordination was typically assigned to a public health surveillance institution and remained there.

The eagerness of NIVEL to embrace digital data collection in the early 1990s led to its running large parts of LINH infrastructure. This in turn provided the foundation for an adjustment of the Sentinel GP Network towards LINH based on the experience and infrastructure available. The integrated coordination of nationwide routine and supplementary data collection in general practice - and subsequently other primary health care providers - for both sentinel surveillance and health services research by the same primary care research institute is another distinctive feature of Dutch primary care monitoring and research. In several other European countries such as England, Belgium, France, and Switzerland, EHR-based general practice research networks developed at institutions different from those already coordinating sentinel networks.

\section{Integration of routine and supplementary data collection: challenges of the transition}

The Dutch example illustrates that the transition of a paper-based into an EHR-based data collection system can take a considerable period of time. In spite of additional resources and more than a decade of experience with LINH at the same institute, computerisation of routine data collection in the sentinel network took much longer than foreseen in the project proposal of 2004, but not much longer than the English WRS that had been computerised a decade before, between 1994 and 1998. The Netherlands have been one of the leading countries in GP EHR utilisation: a 2006 study found that $98 \%$ of Dutch GPs used EHRs (Schoen et al. 2006, p. w558), and a study on GP eHealth utilisation in 2002 and 2007 ranked the Netherlands among the leading EU-15 countries (Ortega Egea et al. 2010, pp. 546-547). Thus, attention needs to be given to the considerable length of time to be allowed for such a transition. Furthermore, the major turnover in GP participation during the transition of the sentinel GP network towards digitalisation demonstrates that even in a country with highly computerised general practice and the professional GP association proposing similar coding standards, the effort necessary to keep the network running during the transition period should not be underestimated. Quality monitoring in the transition period is important, but the Dutch experience shows that it is a challenge to keep GPs motivated to continue the additional work when registering on paper and electronically.

Furthermore, the Dutch were in a fortunate position of being able to carry out the transition with four different EHR software programmes and a website for other GPs. A much greater challenge exists in Belgium, where 15 different recognized GP software programmes co-existed in 2015 (Institut national d'assurance maladieinvalidité (INAMI) (2015) Prime télématique). In the sentinel GP network there, an 
Schweikardt, C., Verheij, R.A., Donker, G.A., Coppieters, Y. The historical development of the Dutch Sentinel General Practice Network from a paper based into a digital primary care monitoring system. Journal of Public Health: 2016, 24(6), 545-562

investigation found nine different EHR software programmes for about $80 \%$ of Belgian sentinel GPs, with only one software programme being used extensively in both Flemish-speaking and French-speaking Belgium (Boffin et al. 2010). Baakman argued that the strongest stimulus for behavioural change in an organisation is the understanding that failure to adapt could lead to its ruin (Baakman 1991, p. 86). It was far from self-evident that the Dutch Sentinel GP Network would survive alongside this promising second computerised GP network, in spite of a health policy climate generally favourable towards primary care. During the 1990s, the Sentinel GP Network demonstrated its added value for infectious disease surveillance in the Netherlands, and NIVEL emerged with a prominent role in European GP network research. The adaptation strategy included an alignment and progressive integration of the Sentinel GP Network, while also (1) contributing to EHR routine registration, (2) continuing to provide supplementary data for in-depth research as added value of the sentinel practices, and (3) implementing innovations in EHR registration so that routine registration supported improved supplementary data collection.

Today, the continued added value of sentinel GP data collection is shown by recent publications on diverse projects such as unwanted pregnancy (Goenee et al. 2014), predictors of gastroenteritis in day-care children (Enserink et al. 2013), and trends in palliative sedation in the Netherlands (Donker et al. 2013).

\section{CONCLUSION}

The Dutch experience is an example of the challenges and opportunities for the established traditional Sentinel GP Network. The main challenge for the network turned out to be a second EHR-based national general practice data collection network in the 1990s against the background of emerging ICT opportunities and new government demands to obtain data on procedures in general practice for health policy planning.

The subsequent adaptation strategy with a transition towards digital data collection led to an integrated national general practice database developing into a primary care database, while preserving complementary data collection for in-depth research. The Dutch experience offers points of attention for the transition period from paper to electronic recording, such as the substantial turnover of reporting GPs comprising the knowledge base for the network.

\section{FOOTNOTES}

1 The name of the Ministry of Health changed over the course of time because the policy areas of public health, social affairs, culture, and sport were grouped in different ways in different periods. See: Rijksoverheid, Ministerie van Volksgezondheid, Welzijn en Sport (n.d.) Geschiedenis: Ministerie van Sociale Zaken en Volksgezondheid (Ministry of Social Affairs and Public Health) 19511971, Ministerie van Volksgezondheid en Milieuhygiëne (Ministry of Public Health and Environmental Hygiene) 1971-1982, Ministerie van Welzijn, Volksgezondheid en Cultuur (Ministry of Well-being, Public Health, and Culture) 1982-1994, Ministerie van Volksgezondheid, Welzijn en Sport (Ministry of Public Health, Wellbeing, and Sport) since 1994. 
Schweikardt, C., Verheij, R.A., Donker, G.A., Coppieters, Y. The historical development of the Dutch Sentinel General Practice Network from a paper based into a digital primary care monitoring system. Journal of Public Health: 2016, 24(6), 545-562

2 Here, we have followed the time frame provided in the biannual report for 1989/1990 (Bartelds 1991) and Dekker et al. 1992. Later reports state 1988-1989.

3 The fluctuation can be observed by comparing the names of participating GPs in the annual reports for 2004 and 2009.

\section{ACKNOWLEDGEMENTS}

We wish to thank the general practitioners who contributed to the Dutch Sentinel GP Network and LINH as well as the health care providers contributing to the NIVEL Primary Care Database. We also wish to thank Dr Aad Bartelds, Professor Bertien Collette, and Professor François Schellevis for their contributions to this article as interview partners.

\section{Compliance with ethical standards}

Conflicts of interests

The first author received a MiniARC grant from the Université libre de Bruxelles (ULB). The other authors declare that they do not have a conflict of interest.

Ethics statement

No patients were involved in this study. Consent was obtained from the three experts to be interviewed and to be named in the acknowledgements. Consent was obtained from expert 2 to be cited in the manuscript.

\section{REFERENCES}

Abrahamse H, Boon W, Esch A, Grol R, Van den Hoogen H, De Jonge JW, Kok F, Van Ooverbeke J, Rutten R, Van Snellenberg H, Van der Veeke M, Van der Velden J (1996) Verslag van het pilot-project 'naar een LINH' [Landelijk Informatie Netwerk Huisartsenzorg] [Report on the pilot project: towards a Netherlands Information Network of General Practice]. NIVEL, Utrecht, The Netherlands.

http://www.nivel.nl/sites/default/files/bestanden/1000025.pdf?. Accessed 09 March 2016

Baakman NAA (1991) Naar marktverhoudingen in de gezondheidszorg? De ziekenhuisbouw tussen 1960 and 1985. In: Van Mierlo JGA (red) Particulier initiatief in de gezondheidszorg. Van Gorcum, Assen, The Netherlands, pp 81-96.

http://digitalarchive.maastrichtuniversity.nl/fedora/get/guid:cf28d5be-772c-4c1a-8046aa4e037ca041/ASSET1. Accessed 09 March 2016

Bartelds AIM (1991) Continue morbiditeits registratie peilstations Nederland 1988/1989 [Continuous Morbidity Registration Sentinel Practices Netherlands 1988/1989] [biannual report]. NIVEL, Utrecht, The Netherlands

Bartelds AIM (1995) Continue morbiditeits registratie peilstations Nederland 1994 [Continuous Morbidity Registration Sentinel Practices Netherlands 1994] [annual report]. NIVEL, Utrecht, The Netherlands

Bartelds AIM (1997) Continue morbiditeits registratie peilstations Nederland 1996

[Continuous Morbidity Registration Sentinel Practices Netherlands 1996] [annual report]. NIVEL, Utrecht, The Netherlands

Bartelds AIM (1998) Continue morbiditeits registratie peilstations Nederland 1997

[Continuous Morbidity Registration Sentinel Practices Netherlands 1997] [annual report]. NIVEL, Utrecht, The Netherlands

Bartelds A. The Dutch Sentinel Network, its present situation and its future. 1999. https://www.wiv-isp.be/Epidemio/epifr/medvfr/mv20an12.pdf. Accessed 03 March 2016 Bartelds AIM (2003) Continue morbiditeits registratie peilstations Nederland 2002

[Continuous Morbidity Registration Sentinel Practices Netherlands 2002] [annual report]. NIVEL, Utrecht, The Netherlands. 
Schweikardt, C., Verheij, R.A., Donker, G.A., Coppieters, Y. The historical development of the Dutch Sentinel General Practice Network from a paper based into a digital primary care monitoring system. Journal of Public Health: 2016, 24(6), 545-562

http://www.nivel.nl/sites/default/files/bestanden/Continue-Morbiditeitsregistratie-

Peilstations-Nederland-verslag-2002.pdf. Accessed 09 March 2016

Bartelds AIM (2004) Continuous morbidity registration at Dutch sentinel stations 2003 [annual report]. NIVEL, Utrecht, The Netherlands.

http://www.nivel.nl/sites/default/files/bestanden/Continuous-Morbidity-Registration-at-

DutchSentinel-Stations-in-2003.pdf. Accessed 04 March 2016

Bartelds AIM (2006) Continuous morbidity registration at Dutch sentinel stations 2004 [annual report]. NIVEL, Utrecht, The Netherlands.

http://www.nivel.nl/sites/default/files/bestanden/int-continuous-morbidity-registration-adutch-sentinel-stations-2004.pdf. Accessed 22 March 2016

Bartelds A, Fracheboud J, Van der Zee J (eds) (1989) The Dutch sentinel practice network: relevance for public health policy. Netherlands Institute of Primary Health Care (NIVEL), Utrecht, The Netherlands

Bensing J (1988) Voorwoord [Preface]. In: Bartelds AIM. Continue morbiditeits registratie peilstations Nederland 1987 [Continuous Morbidity Registration Sentinel Practices Netherlands 1987]. NIVEL, Utrecht, The Netherlands, pp 7-8.

http://www.nivel.nl/sites/default/files/bestanden/1000304.pdf?. Accessed 02 March 2016

Bensing JM, Foets M, Van der Velden J, Van der Zee J (1991) De Nationale Studie van ziekten en verrichtingen in de huisartspraktijk: achtergronden en methoden [The National Survey of Morbidity and Interventions in General Practice: background and methods]. Huisarts en Wetenschap 34(2):51-61. http://nvl002.nivel.nl/postprint/PPpp87.pdf. Accessed 02 March 2016

Boffin N, Bossuyt N, Vanthomme K, Van Casteren V (2010) Readiness of the Belgian network of sentinel general practitioners to deliver electronic health record data for surveillance purposes: results of survey study. BMC Fam Pract 11:50. doi:10.1186/14712296-11-50. http://www.biomedcentral.com.proxy.library.uu.nl/1471-2296/11/50. Accessed 09 March 2015CrossRefPubMedPubMedCentral

Bol FA (1976) [Summary and commentary on] Oberius-Kapteijn JC, Bruins CP. De betekenis van het Nederlands Huisartsen Instituut in de extramurale gezondheidszorg: 'N.H.I.-extra', een beleidsnota. Medisch Contact 31(8):235-239

Boot JM, Knapen MHJM (2005) De Nederlandse gezondheidszorg [Health care in the Netherlands], 8th edn. Bohn Stafleu van Loghum, Houten, The Netherlands

Carbonez F (2010) Le Tableau de Bord de la Fédération des Maisons Médicales. Projet REGM. Ministère de la Santé Publique, Brussels.

http://trix.docpatient.net/files/Projet\%20REGM/reports/tableau_de_bord.pdf. Accessed 09 March 2016

Cash R (2000) THALES: the first patient medical records database in France. Contribution to the EMD Meeting 8 \& 9 December, 2000. Abstract.

http://www.ulb.ac.be/esp/emd/fr_cash.htm. Accessed 09 March 2016

Correa A, Hinton W, McGovern A, Van Vlymen J, Yonova I, Jones S, De Lusignan S (2016)

Royal College of General Practitioners Research and Surveillance Centre (RCGP RSC) sentinel network: a cohort profile. BMJ Open 6(4):e011092. doi:10.1136/bmjopen-2016011092

Crebolder H, Stalman W (2003) De academische werkplaats huisartsgeneeskunde. Huisarts en Wetenschap 46(12):685-689. http://www.henw.org/archief/volledig/id3237-deacademische-werkplaats-huisartsgeneeskunde.html. Accessed 01 March 2016CrossRef

De Bakker D, Abrahamse H, Van den Hoogen H, De Jonge JW, Van Overbeeke H, Rutten, R (1997) Jaarrapport LINH 1996. Contactfrequenties en verrichtingen in het Landelijk Informatie Netwerk Huisartsenzorg (LINH) [Annual report LINH 1996. Contact frequences and activities in the Netherlands Information Network of General Practice (LINH)]. NIVEL, Landelijke Huisartsen Vereniging, Nederlands Huisartsen Genootschap, Werkgroep Onderzoek Kwaliteit, Utrecht, The Netherlands. http://www.nivel.nl/sites/default/files/bestanden/1000290.pdf. Accessed 02.03.2016

De Bakker D, Jabaaij L, Abrahamse H, Van den Hoogen H, Braspenning J, Van Althuis T, Rutten R (2001) Jaarrapport LINH 1999. Contactfrequencies en verrichtingen in het Landelijk Informatie Netwerk Huisartsenzorg (LINH) [Annual Report LINH 1999. Contact frequencies and activities in the Netherlands Information Network of General Practice 
Schweikardt, C., Verheij, R.A., Donker, G.A., Coppieters, Y. The historical development of the Dutch Sentinel General Practice Network from a paper based into a digital primary care monitoring system. Journal of Public Health: 2016, 24(6), 545-562

(LINH)]. NIVEL, Utrecht, The Netherlands.

http://www.nivel.nl/sites/default/files/bestanden/1000034.pdf. Accessed 09 March 2016

De Pange M-F (2004) Pourquoi participer à un observatoire épidémiologique. Informatique et web. Le quotidien du médecin, 14.05.2004:10-11.

http://omg.sfmg.org/docs/presse/article_pano_observatoires.pdf. Accessed 07 March 2016

De Wit MAS, Koopmans MPG, Kortbeek LM, Van Leeuwen WJ, Vinjé J, Bartelds AIM, Van

Duynhoven YTHP (1999) Interim report of a study on gastroenteritis in sentinel practices in the Netherlands (NIVEL) 1996-1999. Results of the first two years. RIVM, Bilthoven, The

Netherlands. http://rivm.openrepository.com/rivm/bitstream/10029/9920/1/216852003.pdf. Accessed 03 March 2016

De Wit MAS, Koopmans MPG, Kortbeek LM, Van Leeuwen NJ, Bartelds AIM, Van Duynhoven YTHP (2001) Gastroenteritis in sentinel general practices, the Netherlands. Emerg Infect Dis 7(1):82-91.

http://wwwnc.cdc.gov.proxy.library.uu.nl/eid/article/7/1/pdfs/70-0082.pdf. Accessed 03 March 2016CrossRefPubMedPubMedCentral

Deckers JGM, Schellevis FG (2004) Health information from primary care: final report.

December 1, 2001 - March 31, 2004. Programme: Health Monitoring, Directorate General

SanCo, European Commission. Project no. 2001/IND/2096. NIVEL, Utrecht, The

Netherlands. http://www.nivel.nl/sites/default/files/bestanden/health-info-from-primary-caremet-appendixes.pdf. Accessed 02 March 2016

Deckers JGM, Paget WJ, Schellevis FG, Fleming DM (2006) European primary care surveillance networks: their structure and operation. Fam Pract 23(2):151-158.

doi:10.1093/fampra/cmi118,

http://fampra.oxfordjournals.org.proxy.library.uu.nl/content/23/2/151.full.pdf+html. Accessed 01 March 2016CrossRefPubMed

Dekker J, Driessen M-J, Stumpel H, Winckers M, Bartelds AIM (1992) Verwijzingen door huisartsen naar logopedisten: huisartsen en andere personen als signaleerders van stoornissen. Huisarts en Wetenschap 35(11):425-427.

https://nvl002.nivel.nl/postprint/PPpp227.pdf?. Accessed 09 March 2016

Donker GA (2011) Continuous morbidity registration at Dutch sentinel general practice network 2009 [annual report]. NIVEL, Utrecht, The Netherlands.

http://www.nivel.nl/sites/default/files/bestanden/Rapport-CMR-sentinel-general-practicenetwork-2009.pdf. Accessed 01 March 2016

Donker GA (2014) Continuous morbidity registration Dutch sentinel general practice network 2012 [annual report]. NIVEL, Utrecht, The Netherlands.

http://www.nivel.nl/sites/default/files/bestanden/Rapport-continuous-morbidity-registrationdutch-sentinel-2012.pdf. Accessed 04 March 2016

Donker GA (2015) NIVEL Primary Care Database - sentinel practices 2013 [annual report]. NIVEL, Utrecht,The Netherlands.

http://www.nivel.nl/sites/default/files/bestanden/Peilstations-jaarverslag-2013-Engels.pdf.

Accessed 02 March 2016

Donker GA (2016) NIVEL Primary Care Database - sentinel practices 2014 [annual report]. NIVEL, Utrecht, The Netherlands. http://www.nivel.nl/en/nivel-primary-care-database-

Sentinel-Practices\%20. Accessed 09 March 2016

Donker GA, Slotman FG, Spreeuwenberg P, Francke AL (2013) Palliative sedation in Dutch general practice from 2005 to 2011: a dynamic cohort study of trends and reasons. $\mathrm{Br} \mathrm{J}$ Gen Pract 63(615):e669-e675. doi:10.3399/bjgp13X673676.

http://www.ncbi.nlm.nih.gov.proxy.library.uu.nl/pmc/articles/PMC3782799/pdf/bjgpoct2013-63-615-e669.pdf. Accessed 09 March 2016CrossRefPubMedPubMedCentral

Enserink R, Ypma R, Donker GA, Smit HA, Van Pelt W (2013) Infectious disease burden related to child day care in the Netherlands. Pediatr Infect Dis J 32(8):e334-e340.

doi:10.1097/INF.0b013e318290601e PubMed

European Centre for Disease Prevention and Control (ECDC). Influenza surveillance. Sentinel surveillance.

http://ecdc.europa.eu.proxy.library.uu.nl/en/activities/surveillance/EISN/surveillance/Pages/ sentinel_surveillance.aspx. Accessed 21 May 2015

European Influenza Surveillance Scheme (2001) Annual Report. 2000-2001 influenza season. NIVEL, Utrecht, The Netherlands. 
Schweikardt, C., Verheij, R.A., Donker, G.A., Coppieters, Y. The historical development of the Dutch Sentinel General Practice Network from a paper based into a digital primary care monitoring system. Journal of Public Health: 2016, 24(6), 545-562

http://ec.europa.eu.proxy.library.uu.nl/health/ph_projects/1999/com_diseases/fp_commdis_ 1999_frep_16_en.pdf. Accessed 03 March 2016

Flahault A, Valleron A-J (1997) Le réseau Sentinelles. Douze années de recherches et de surveillance sur les maladies transmissibles en France. Actualité et dossier en santé publique 18:22-25. http://www.hcsp.fr/docspdf/adsp/adsp-18/ad185457.pdf. Accessed 01 March 2016

Fleming DM (1991) The measurement of morbidity in general practice. J Epidemiol Comm Health 45(3):180-183.

http://www.ncbi.nlm.nih.gov.proxy.library.uu.nl/pmc/articles/PMC1060754/pdf/jepicomh002 16-0006.pdf. Accessed 01 March 2016CrossRef

Fleming DM (1998) The role of research networks in primary care. Based on a presentation at WONCA Dublin in June 1998. Eur J Gen Pract 4(3):96-99.

doi:10.3109/13814789809160358 CrossRef

Fleming DM (1999) Weekly returns service of the royal college of general practitioners. Commun Dis Public Health 2(2):96-100PubMed

Fleming DM (2011) RCGP Weekly Returns Service data extraction. Nottingham meeting Sept 22 2011. https://www.openpseudonymiser.org/Resources/RCGP\%20approach.pptx. Accessed 04 March 2016

Fleming DM, Elliot AJ (2006) Changing disease incidence: the consulting room perspective. Br J Gen Pract 56(532):820-824.

http://www.ncbi.nlm.nih.gov.proxy.library.uu.nl/pmc/articles/PMC1927088/pdf/bjpg56820.pdf. Accessed 09 March 2016PubMedPubMedCentral

Fleming DM, Schellevis FG, Paget WJ (2001) Health monitoring in sentinel practice networks. Final report. NIVEL, Utrecht, The Netherlands.

http://ec.europa.eu.proxy.library.uu.nl/health/ph_projects/1998/monitoring/fp_monitoring_1 998_frep_05_en.pdf. Accessed 03 March 2016

Fleming DM, Schellevis FG, Paget WJ (2003) Health monitoring in sentinel practice networks. The contribution of primary care. Eur J Public Health 13(3 Suppl):80-84. doi:10.1093/eurpub/13.suppl_1.80 CrossRefPubMed

Garnerin P, Saidi Y, Valleron AJ (1992) The French communicable diseases computer network: a seven-year experiment. Ann N Y Acad Sci 670:29-42. doi:10.1111/j.17496632.1992.tb26072.x CrossRefPubMed

Geneeskundig inspecteur voor infectieziekten dr. H. Bijkerk is teruggetreden (1989) Nederlands Tijdschrift voor Geneeskunde 133(2):94. https://www-ntvgnl.proxy.library.uu.nl/system/files/publications/1989100940002a.pdf. Accessed 02 March 2016

Goenee MS, Donker GA, Picavet C, Wijsen C (2014) Decision-making concerning unwanted pregnancy in general practice. Fam Pract 31(5):564-570. doi:10.1093/fampra/cmu033. http://fampra.oxfordjournals.org.proxy.library.uu.nl/content/31/5/564.full.pdf+html. Accessed 09 March 2016CrossRefPubMed

Granja M, Ponte C, Cavadas LF (2014) What keeps family physicians busy in Portugal? A multicentre observational study of work other than direct patient contacts. BMJ Open 4:e005026. doi:10.1136/bmjopen-2014-005026.

http://bmjopen.bmj.com.proxy.library.uu.nl/content/4/6/e005026.full.pdf+html. Accessed 07 March 2016CrossRefPubMedPubMedCentral

Griffiths F, Wild A, Harvey J, Fenton E (2000) The productivity of primary care research networks. Br J Gen Pract 50(460):913-915, http://www.ncbi.nlm.nih.gov.proxy.library.uu.nl/pmc/articles/PMC1313857/pdf/11141879.pd f. Accessed 09 March 2016PubMedPubMedCentral

Groenewegen P, Van der Zee J (1979) Bouwstenen voor een vestigingsbeleid van huisartsen. Medisch Contact 34(21):671-677

Hart HE, Van der Wouden JC, Höppener P, Van Schendel GJ, Knottnerus JA (1999) General practice registration networks in the Netherlands: a brief report. J Am Med Inform Assoc 6(2):173-175.

http://www.ncbi.nlm.nih.gov.proxy.library.uu.nl/pmc/articles/PMC61356/pdf/0060173.pdf. Accessed 09 March 2016CrossRefPubMedPubMedCentral

Heijnen MLA, De Boer AS (1998) Respiratoire infecties in Nederland. Beperkte surveillance gegevens van Chlamydia pneumoniae. Infectieziekten Bull 9(10):251-252, 
Schweikardt, C., Verheij, R.A., Donker, G.A., Coppieters, Y. The historical development of the Dutch Sentinel General Practice Network from a paper based into a digital primary care monitoring system. Journal of Public Health: 2016, 24(6), 545-562

http://rivm.nl/dsresource?type=pdf\&objectid=rivmp:63130\&versionid=\&subobjectname=. Accessed 03 March 2016

Hoogleraar Richard Grol neemt afscheid van het kwaliteitsonderzoek. "De toekomst ligt in multidisciplinair samenwerken" (2011) TvZ Tijdschrift voor Verpleegkundigen 121(2):2831. http://www.nursing.nl/PageFiles/9964/2011,_2-28.pdf. Accessed 02 March 2016 Independent Scientific Advisory Committee for Medicines and Healthcare products Regulatory Agency (MHRA) database research (ISAC) (n.d.) Annual Report Jan 2012-Dec 2012. ISAC Annual Report 2012 v1.8.

https://www.cprd.com/_docs/ISAC\%20Annual\%20Report_2012.pdf. Accessed 04 March 2016

Institut national d'assurance maladie-invalidité (INAMI) (2015) Prime télématique pour les médecins généralistes. Dernière mise à jour 01 juin 2015.

http://www.inami.fgov.be/fr/professionnels/sante/medecins/aide/Pages/prime-telematiquemedecins-generalistes.aspx\#.VuAN0-ZyW3E. Accessed 09 March 2016

Institut national de la santé et de la recherche médicale (Inserm) / University Paris VI Pierre et Marie Curie (n.d.) Le Réseau Sentinelles. Présentation.

https://websenti.u707.jussieu.fr/sentiweb/?page=presentation. Accessed 04 March 2016

Istituto di Ricerca della Società Italiana di Medicina Generale (SIMG) (n.d.) Health Search. http://www.healthsearch.it/?lang=en. Accessed 09 March 2016

Junta de Castilla y León, Consejería de Sanidad (n.d.) ¿Qué es la Red Centinela Sanitaria de Castilla y León? http://www.saludcastillayleon.es/profesionales/es/centinelas/redcentinela-sanitaria-castilla-leon. Accessed 04 March 2016

Junta de Castilla y León, Consejería de Sanidad (n.d.) Nueva recogida de información de la "Cohorte de diabetes de Castilla y León".

http://www.saludcastillayleon.es/profesionales/es/centinelas/cohorte-diabetes/nuevarecogida-informacion-cohorte-diabetes-castilla-leon. Accessed 29 February 2016

Junta de Castilla y León, Consejería de Sanidad (2011) Procedimientos y documentación de la Red Centinela Sanitaria de Castilla y León. Versión 3.0. Enero 2011.

http://www.saludcastillayleon.es/profesionales/es/centinelas/red-centinela-sanitaria-castillaleon.ficheros/84419-

Procedimientos\%20y\%20documentaci\%C3\%B3n\%20de\%20la\%20Red\%20Centinela\%20 Sanitaria\%20de\%20Castilla\%20y\%20Le\%C3\%B3n\%20_v\%203_.pdf. Accessed 09 March 2016

Kuchinke W, Ohmann C, Verheij RA, Van Veen E-B, Delaney BC (2016) Development towards a learning health system - experiences with the privacy protection model of the TRANSFoRm project. In: Gutwirth S, Leenes R, De Hert P (eds) Data protection on the move: current developments in ICT and privacy/data protection. Springer, Dordrecht, The Netherlands. pp 101-134

Loudon I (2008) The principle of referral: the gatekeeping role of the GP. Br J Gen Pract 58(547):128-130. doi:10.3399/bjgp08X277113.

http://www.ncbi.nlm.nih.gov.proxy.library.uu.nl/pmc/articles/PMC2233970/pdf/bjgp58128.pdf. Accessed 01 March 2013CrossRefPubMedPubMedCentral

Ministry of Health (Ministerie van Sociale Zaken en Volksgezondheid), de Minister van Sociale Zaken en Volksgezondheid, G. M. J. Veldkamp, de Staatssecretaris van Sociale Zaken en Volksgezondheid, A. Bartels (1966) Volksgezondheidsnota [Public health policy plan] 1966. [Staatsuitgeverij,'s-Gravenhage].

http://resourcessgd.kb.nl/SGD/19651966/PDF/SGD_19651966_0002538.pdf. Accessed 01 March 2016

Ministry of Health, de Staatssecretaris van Volksgezondheid en Milieuhygiëne, E. VederSmit (1980) Schets van de Eerstelijnsgezondheidszorg [Outline Primary Health Care]. Tweede Kamer, zitting 1979-1980. 18.02.1980. 16066, nos. 1-2.

http://resolver.kb.nl/resolve?urn=sgd\%3Ampeg21\%3A19791980\%3A0007194, http://resolver.kb.nl/resolve?urn=sgd\%3Ampeg21\%3A19791980\%3A0007195. Accessed 02 March 2016

Ministry of Health, de Staatssecretaris van Welzijn, Volksgezondheid en Cultuur, J. P. van der Reijden (1983) Nota Eerstelijnszorg [Policy Programme Primary Care]. Tweede Kamer, vergaderjaar 1983-1984, 02.12.1983. 18180, nos. 1-2,

http://resolver.kb.nl/resolve?urn=sgd\%3Ampeg21\%3A19831984\%3A0007033, 
Schweikardt, C., Verheij, R.A., Donker, G.A., Coppieters, Y. The historical development of the Dutch Sentinel General Practice Network from a paper based into a digital primary care monitoring system. Journal of Public Health: 2016, 24(6), 545-562

http://resourcessgd.kb.nl/SGD/19831984/PDF/SGD_19831984_0006771.pdf. Accessed 02 March 2016

Ministry of Health, de Minister van Welzijn, Volksgezondheid en Cultuur, H. d'Ancona, de Staatssecretaris van Welzijn, Volksgezondheid en Cultuur, H. J. Simons (1991) Financieel Overzicht Zorg 1992 [Financial Overview Care 1992]. Tweede Kamer, vergaderjaar 19911992, 23.09.1991, 22311, nos. 1-2, http://resolver.kb.nl/resolve?urn=sgd\%3Ampeg21\%3A19911992\%3A0005402, http://resolver3.kb.nl/resolve?urn=sgd\%3Ampeg21\%3A19911992\%3A0005403. Accessed 02 March 2016

Ministry of Health, de Minister van Volksgezondheid, Welzijn en Sport, E. Borst-Eilers, de Staatssekretaris van Volksgezondheid, Welzijn en Sport, E.G. Terpstra (1994) Financieel Overzicht Zorg 1995 [Financial Overview Care 1995]. Tweede Kamer, vergaderjaar 19941995, 22.09.1994. 23904, nos. 1-2.

http://resolver.kb.nl/resolve?urn=sgd\%3Ampeg21\%3A19941995\%3A0001830, http://resourcessgd.kb.nl/SGD/19941995/PDF/SGD_19941995_0001776.pdf. Accessed 03 March 2016

Ministry of Health, de Minister en de Staatssecretaris van Volksgezondheid, Welzijn en Sport, E. Borst-Eilers, de Staatssecretaris van Volksgezondheid, Welzijn en Sport, M. Vliegenthart (1999). Zorgnota 2000, 21.09.1999. 26801, nos. 1-2.

https://zoek.officielebekendmakingen.nl/kst-26801-1.pdf. Accessed 03 March 2016

Ministry of Health, Ministerie van Volksgezondheid, Welzijn en Sport, Landelijke

Coördinatiestructuur Infectieziektebestrijding (2004) Beleidsdraaiboek Influenzapandemie, versie 010704.

http://www.fao.org.proxy.library.uu.nl/docs/eims/upload/221499/national_plan_ai_nld_dutch .pdf. Accessed 03 March 2016

Muñoz-Ortego J, Vestergaard P, Blanch Rubio J, Wordsworth P, Judge A, Kassim Javaid M, Arden NK, Cooper C, Díez-Pérez A, Prieto-Alhambra D (2014) Ankylosing spondylitis is associated with an increased risk of vertebral and nonvertebral clinical fractures: a population-based cohort study. J Bone Miner Res 29(8):1770-1776. doi:10.1002/jbmr.2217. http://onlinelibrary.wiley.com.proxy.library.uu.nl, doi:10.1002/jbmr.2217/epdf. Accessed 07 March 2016CrossRefPubMed

National Health Institute Doutor Ricardo Jorge (INSA) (2008) Plataforma RIOS já engloba sete redes de vigilância. 23.07.2008.

http://www.insa.pt/sites/INSA/Portugues/Comlnf/Noticias/Paginas/PlataformaRIOS.aspx. Accessed 04 March 2016

National Health Institute Doutor Ricardo Jorge (INSA) (n.d.) Rede Médicos Sentinela. http://www.insa.pt/sites/INSA/Portugues/AreasCientificas/Epidemiologia/Unidades/UnInstr Obser/Paginas/MS.aspx. Accessed 04 March 2016

Nederlands Huisartsen Genootschap, werkgroep: De Jong H, Kole H, Metsemakers JFM, Peerden H, Smit C, Stroucken J, Buiting C, redactie Njoo KH (2004) Richtlijn Adequate dossiervorming met het Elektronisch Medisch Dossier. Nederlands Huisartsen Genootschap, Utrecht, The Netherlands

NIH National Cancer Institute (2013) Base de datos para la Investigacion Farmacoepedemiologica en Atencion Primaria (BIFAP). Last Updated: 12 September 2013. http://epi.grants.cancer.gov/pharm/pharmacoepi_db/bifap.html. Accessed 07 March 2016

NIVEL (n.d.) NIVEL Zorgregistraties eerste lijn. http://www.nivel.nl/NZR/zorgregistratieseerstelijn. Accessed 16 June 2016. English version (less detailed): NIVEL Primary Care Database. http://www.nivel.nl/en/dossier/nivel-primary-care-database. Accessed 04 March 2016

Organize and Promote Epidemiological Network, Réseau d'Observation des Maladies et d'Epidémies (Open Rome) (n.d.) Bienvenue sur le site d'Open Rome. http://www.openrome.org/. Accessed 16 June 2016

Organize and Promote Epidemiological Network, Réseau d'Observation des Maladies et d'Epidémies (Open Rome) (2013) Réseaux des GROG (updated 13.08.2013). http://www.openrome.org/epi/grog.html . Accessed 09 March 2016

Ortega Egea JM, Román González MV, Recio Menéndez M (2010) eHealth usage patterns of European general practitioners: a five-year (2002-2007) comparative study. Int J Med 
Schweikardt, C., Verheij, R.A., Donker, G.A., Coppieters, Y. The historical development of the Dutch Sentinel General Practice Network from a paper based into a digital primary care monitoring system. Journal of Public Health: 2016, 24(6), 545-562

Inform 79(8):539-553. doi:10.1016/j.jmedinf.2010.05.003.

http://www.sciencedirect.com.proxy.library.uu.nl/science/article/pii/S1386505610000997. Accessed 07 March 2016CrossRefPubMed

Overeenkomst inzake peilstations voor de volksgezondheid (Persbericht Ministerie van Sociale Zaken en Volksgezondheid, 11 december) [Agreement on sentinel practices for public health (press release by the Ministry of Social Affairs and Public Health)] (1969). Nederlands Tijdschrift voor Geneeskunde 113(1):46. https://www-ntvgnl.proxy.library.uu.nl/system/files/publications/1969100460003a.pdf. Accessed 02 March 2016

Pedersen KM, Andersen JS, Søndergaard J (2012) General practice and primary health care in Denmark. J Am Board Fam Med 25(Suppl 1):S34-S38.

doi:10.3122/jabfm.2012.02.110216.

http://www.jabfm.org/content/25/Suppl_1/S34.full.pdf+html. Accessed 09 March 2016CrossRefPubMed

Prins M, Hek K, Verberne L, Nielen M, Opperhuizen G, Verheij R (2015) Zorg door de huisarts. Jaarcijfers 2014 en trendcijfers 2010-2014. Rapport NIVEL Zorgregistraties eerste lijn. NIVEL, Utrecht, The Netherlands.

http://www.nivel.nl/sites/default/files/Jaarrapport_huisarts2014.pdf. Accessed 04 March 2016

[Programme Committee Sentinel Practices] [ Programmacommissie Peilstations] (1971) Continue morbiditeits registratie peilstations jaarverslag 1970. Continuous Morbidity Registration Sentinel Stations Annual Report 1970 (with a summary in English). Ministerie van Volksgezondheid en Milieuhygiëne, Leidschendam; Nederlands Huisartsen Instituut, Utrecht, The Netherlands

[Programme Committee Sentinel Practices] [Programmacommissie Peilstations] (1973) Continue morbiditeits registratie peilstations jaarverslag 1972 [annual report]. Ministerie van Volksgezondheid en Milieuhygiëne, Leidschendam; Nederlands Huisartsen Instituut, Utrecht, The Netherlands

[Programme Committee Sentinel Practices] [Programmacommissie Peilstations] (1974) Continue morbiditeits registratie peilstations jaarverslag 1973 [annual report]. Ministerie van Volksgezondheid en Milieuhygiëne, Leidschendam; Nederlands Huisartsen Instituut; Utrecht, The Netherlands

Rijksoverheid, Ministerie van Volksgezondheid, Welzijn en Sport (n.d.) Geschiedenis. Een kort overzicht van de geschiedenis van het ministerie van Volksgezondheid, Welzijn en Sport vanaf 1800. https://www.rijksoverheid.nl/ministeries/ministerie-van-volksgezondheidwelzijn-en-sport/inhoud/organisatie/geschiedenis. Accessed 01 March 2016

Royal College of General Practitioners, Research \& Surveillance Centre, Fleming DM, Spofforth N, Barley MA, Grant SJ, Durnall H, Postle H (n.d.) Royal College of General Practitioners Weekly Returns Service Annual Report 2011, Royal College of General Practitioners, London

Saludadiario.es. Por S. A. D. (2015) En Castilla y León. Arranca la campaña de vacunación frente a la gripe, que durará siete semanas. La Junta ha distribuido 640.000 dosis de tres tipos vacunales diferentes para su administración según la edad, 20.10.2015.

http://www.saludadiario.es/centros-de-salud/arranca-la-campana-de-vacunacion-frente-ala-gripe-que-durara-siete-semanas. Accessed 09 March 2016

Salvador Rosa A, Moreno Pérez JC, Sonego D, García Rodríguez LA, de Abajo Iglesias FJ (2002) El proyecto BIFAP: base de datos para la investigación farmacoepidemiológica en atención primaria. Aten Primaria 30(10):655-661. http://www.elsevier.es/es-revistaatencion-primaria-27-linkresolver-el-proyecto-bifap-base-datos-13041211. Accessed 07 March 2016CrossRefPubMed

Schellevis FG (2011) Foreword. In: Donker GA (2011) Continuous Morbidity Registration at Dutch Sentinel General Practice Network 2009 [annual report]. NIVEL, Utrecht, The Netherlands, pp 5-6. http://www.nivel.nl/sites/default/files/bestanden/Rapport-CMRsentinel-general-practice-network-2009.pdf. Accessed 01 March 2016

Schellevis FG, Westert GP, De Bakker DH, Groenewegen PP (2004) Tweede nationale studie naar ziekten en verrichtingen in de huisartspraktijk. Vraagstellingen en methoden [Second Dutch National Survey of General Practice. Questions and Methods]. NIVEL, Utrecht, The Netherlands. 
Schweikardt, C., Verheij, R.A., Donker, G.A., Coppieters, Y. The historical development of the Dutch Sentinel General Practice Network from a paper based into a digital primary care monitoring system. Journal of Public Health: 2016, 24(6), 545-562

http://www.nivel.nl/sites/default/files/bestanden/ns2_rapport00.pdf. Accessed 01 March 2016

Schellevis FG, Westert GP, De Bakker DH (2005) The actual role of general practice in the Dutch health-care system: results of the Second Dutch National Survey of General Practice. J Public Health 13(5):265-269. doi:10.1007/s10389-005-0124-z CrossRef Schellevis F, Donker GA, Verheij RA (2009) Het gebruik van het elektronisch patiënten dossier voor onderzoek naar morbiditeit en zorggebruik in de Continue Morbiditeitsregistratie Peilstations Nederland [The use of the electronic patient record for research on morbidity and care utilisation in Continuous Morbidity Registration Sentinel Practices in the Netherlands]. In: Peeters, J (ed) Huisartsenpeilpraktijken: 30 jaar. Registratie van de morbiditeit in België. Het Verleden, een Succes-de Toekomst, een Uitdaging [GP sentinel practices: 30 years. Registration of morbidity in Belgium. The past, a success-the future, a challenge]. WIV-ISP, Brussels, pp 19-20

Schoen C, Osborn R, Huynh PT, Doty M, Peugh J, Zapert K (2006) On the front lines of care: primary care doctors' office systems, experiences, and views in seven countries. Health Aff (Millwood).25(6):w555—571. doi: 10.1377/hlthaff.25.w555.

http://content.healthaffairs.org.proxy.library.uu.nl/content/25/6/w555.full.pdf+html. Accessed 09 March 2016

Schweizerische Eidgenossenschaft, Bundesamt für Gesundheit (n.d.) Das schweizerische Sentinella-Meldesystem.

http://www.bag.admin.ch/k_m_meldesystem/00736/00817/index.html?lang=de. Accessed 04 March2016

Scientific Institute of Public Health (WIV-ISP) (n.d.) Healthdata.be: une nouvelle plateforme internet pour faciliter et standardiser l'enregistrement des données de santé. https://www.wivisp.be/News/Pages/Healthdatabeunenouvelleplateformeinternetpourfaciliteretstandardiserl \%E2\%80\%99enregistrementdesdonn\%C3\%A9esdesant\%C3\%A9.aspx. Accessed 07 March 2016

Scientific Institute of Public Health (n.d.) Healthdata. Collecte des données. http://www.healthdata.be/fr/datacollection/. Accessed 04 March 2016

Scientific Institute of Public Health (n.d.) Healthdata. Sur Healthdata.be. http://www.healthdata.be/fr/healthdatabe/. Accessed 09 March 2016

Sentinella (n.d.) Themenübersicht Allgemeinpraktiker. http://www.sentinella.ch/de/subject/generalists. Accessed 01 March 2016

SIDIAP Information System for the Improvement of Research in Primary Care (n.d.) Background. http://www.sidiap.org/index.php/en/introduction/background. Accessed 09 March 2016

Société Française de Médécine Générale (2012) L'avenir de l'Observatoire de la Médecine Générale. L'OMG est provisoirement fermé, en attendant de trouver un nouveau modèle économique. Communiqué, 04.01.2012.

http://www.sfmg.org/actualites/communiques/l_avenir_de_I_observatoire_de_la_medecine generale.html. Accessed 07 March 2016

Sprenger MJW, Schrijnemakers PM (1998) Meer informatie over infectieziekten door landelijk systeem. Ned Tijdschr Geneeskd 142(34):1923-1926. https://www-ntvgnl.proxy.library.uu.nl/system/files/publications/1998119230001a.pdf. Accessed 03 March 2016PubMed

Streit S, Kaplan V, Busato A, Djalali S, Senn O, Meli DN, FIRE Study Group (2015) General Practitioners' vitamin $\mathrm{K}$ antagonist monitoring is associated with better blood pressure control in patients with hypertension: a cross-sectional database study. BMC Cardiovasc Disord 15:47. doi:10.1186/s12872-015-0053-x.

http://www.ncbi.nlm.nih.gov.proxy.library.uu.nl/pmc/articles/PMC4461926/. Accessed 07 March 2016CrossRefPubMedPubMedCentral

Sullivan F, Butler C, Cupples M, Kinmonth A-L (2007) Primary care research networks in the United Kingdom. BMJ 334(7603):1093-1094. doi:10.1136/bmj.39190.648785.80, http://www.bmj.com.proxy.library.uu.nl/content/bmj/334/7603/1093.full.pdf. Accessed 04 March 2016CrossRefPubMedPubMedCentral 
Schweikardt, C., Verheij, R.A., Donker, G.A., Coppieters, Y. The historical development of the Dutch Sentinel General Practice Network from a paper based into a digital primary care monitoring system. Journal of Public Health: 2016, 24(6), 545-562

Swiss Federal Office of Public Health (n.d.) The Swiss Sentinel Surveillance Network, http://www.bag.admin.ch/k_m_meldesystem/00736/00817/index.html?lang=en. Accessed 04 March 2016

The Royal College of General Practitioners' Weekly Returns Service (2002) In: PHLS Communicable Disease Surveillance Centre (ed) CDR Weekly 12(21), 23.05.2002:10-11. Last updated 23 May 2002.

http://webarchive.nationalarchives.gov.uk/+/http://www.hpa.org.uk/cdr/archives/2002/cdr21 02.pdf. Accessed 01 March 2016

Thomas P, Griffiths F, Kai J, O'Dwyer A (2001) Networks for research in primary health care. BMJ 322(7286):588-590.

http://www.ncbi.nlm.nih.gov.proxy.library.uu.nl/pmc/articles/PMC1119786/pdf/588.pdf. Accessed 01 March 2016CrossRefPubMed

Tielens VCL (2002) Voorwoord. In: Verheij R, Jabaaij L, De Bakker D, Abrahamse H, Van den Hoogen H, Braspenning J, Van Althuis T, Rutten R (2002) LINH jaarrapport 2001. Cijfers uit het Landelijk Informatie Netwerk Huisartsenzorg: contacten, verwijzingen en voorschrijven in de huisartspraktijk. Utrecht, Nijmegen; NIVEL, Landelijke Huisartsen Vereniging, Nederlands Huisartsen Genootschap, Werkgroep Onderzoek Kwaliteit. http://www.nivel.nl/sites/default/files/bestanden/linh-2001.pdf. Accessed 01 March 2016

Truyers C, Elli S, Goderis G, Buntinx F (2015) 20 jaar huisartspraktijk in Vlaanderen (19942013). Acco, Leuven, The Netherlands

Turbelin C, Boëlle P-Y (2010) Improving general practice based epidemiologic surveillance using desktop clients: the French Sentinel Network experience. Stud Health Technol Inform 160(Pt 1):442-446. doi: 10.3233/978-1-60750-588-4-442.

http://www.ncbi.nlm.nih.gov.proxy.library.uu.nl/pmc/articles/PMC3948144/. [author manuscript] Accessed 09 March 2016

Tweede Kamer der Staten-Generaal, 2. Vergaderjaar 1984-1985 (1985) Beroepskrachtenplanning Gezondheidszorg en Maatschappelijke Dienstverlening, 18920. http://resourcessgd.kb.nl/SGD/19841985/PDF/SGD_19841985_0008018.pdf. Accessed 02 March 2016

Tweede Kamer, vaste commissie voor Volksgezondheid, Welzijn en Sport, de voorzitter van de commissie, Netelenbos, de griffier van de commissie, Teunissen (2002) Vaststelling van de begrotingsstaat van het Ministerie van Volksgezondheid, Welzijn en Sport (XVI) voor het jaar 2003, $28600 \mathrm{XVI}$, nr. 25, verslag van een schriftelijk overleg. Vastgesteld $22 \mathrm{Nov}$ 2002. https://zoek.officielebekendmakingen.nl/kst-28600-XVI-25.pdf. Accessed 04 March 2016

Universität Zürich, Hausarztmedizin - FIRE (n.d.) Das FIRE-Projekt. http://www.hausarztmedizin.uzh.ch/fire2.html. Accessed 07 March 2016

Valenciano M, Ciancio BC, Moren A, the influenza vaccine effectiveness working group (2008) First steps in the design of a system to monitor vaccine effectiveness during seasonal and pandemic influenza in EU/EEA Member States. Euro Surveill. Oct 23, 13(43): : ii = 19015.

http://www.eurosurveillance.org.proxy.library.uu.nl/ViewArticle.aspx?Articleld=19015. Accessed 01 March 2016

Van Casteren V (1991) Inventory of Sentinel Health Information Systems with GPs in the European Community. Situation Up to March 1990. Institute of Hygiene and Epidemiology, Brussels

Van Casteren V (1993) Eurosentinel. In: Fracchia GN, Theofilatou M (eds) Health services research. Commission of the European Communities, Directorate-General for Science, Research and Development. IOS Press, Amsterdam, pp 253-262

Van Casteren V (2009) Evolutie van 1979 tot nu [Evolution since 1979 until now]. In: Peeters $\mathrm{J}$ (ed) Huisartsenpeilpraktijken: 30 jaar. Registratie van de morbiditeit in belgië: het verleden, een succes-De toekomst, een uitdaging [GP sentinel practices: 30 years. Registration of morbidity in Belgium: the past, a success-the future, a challenge]. WIVISP, Brussels, pp 5-17

Van der Avoort C, Faber M, Groeneveld J, Grol R (redaction) (2008) IQ healthcare, een nieuwe naam voor kwaliteit. Scientific Institute for Quality of Healthcare, UMC St Radboud, Nijmegen, The Netherlands 
Schweikardt, C., Verheij, R.A., Donker, G.A., Coppieters, Y. The historical development of the Dutch Sentinel General Practice Network from a paper based into a digital primary care monitoring system. Journal of Public Health: 2016, 24(6), 545-562

Van der Bij S, Khan N, Ten Veen P, De Bakker DH, Verheij RA (2016) Improving the quality of EHR recording in primary care: a data quality feedback tool. J Am Medical Informatics Assoc (Advance Access published June 6, 2016). doi:10.1093/jamia/ocw054ocw054

Van Es JC (2006) Een halve eeuw huisartsgeneeskunde: van ambacht naar professie-een terugblik [A half century of general practice: from craft to profession-a look back]. Bohn Stafleu van Loghum, Houten, The Netherlands

Vega Alonso AT, Zurriaga Llorens O, Galmés Truyols A, Lozano Alonso JE, Paisán Maestro L, Gil Costa M, Herrero Llorente A, Ramos Aceitero JM; en nombre del grupo de investigadores del proyecto RECENT (2006) Redes centinela sanitarias en España. Consenso para una guía de principios y métodos. [Health sentinel networks in Spain. Consensus for a guide of principles and methods]. Gac Sanit 20(6):496-502. http://www.scielosp.org.proxy.library.uu.nl/pdf/gs/v20n6/especial.pdf. Accessed 04 March 2016

Verheij R, Jabaaij L, De Bakker D, Abrahamse H, Van den Hoogen $\mathrm{H}$, Braspenning J, Van Althuis T, Rutten R (2002) LINH jaarrapport 2001. Cijfers uit het Landelijk Informatie Netwerk Huisartsenzorg: contacten, verwijzingen en voorschrijven in de huisartspraktijk. NIVEL, Landelijke Huisartsen Vereniging, Nederlands Huisartsen Genootschap, Werkgroep Onderzoek Kwaliteit, Utrecht, Nijmegen, The Netherlands. http://www.nivel.nl/sites/default/files/bestanden/linh-2001.pdf. Accessed 01 March 2016

Verheij RA, Van Dijk CE, Abrahamse H, Davids R, Wennekes L, Van den Hoogen H, Visscher S, Braspenning J, Van Althuis T (2010) Landelijk informatie netwerk huisartsenzorg (LINH). kerncijfers 2008. NIVEL, Utrecht, The Netherlands. http://www.nivel.nl/sites/default/files/bestanden/Rapport-kerncijfers-LINH-2008.pdf. Accessed 01 March 2016

Wiegers T, Hopman P, Kringos D, De Bakker D (2011) NIVEL Overzichtstudies: de eerste lijn. NIVEL, Utrecht, The Netherlands.

http://www.nivel.nl/sites/default/files/bestanden/Rapport-overzichtsstudie-eerste\%20lijn.pdf. Accessed 01 March 2016

Williams T, Van Staa T, Puri S, Eaton S (2012) Recent advances in the utility and use of the general practice research database as an example of a UK primary care data resource. Ther Adv Drug Saf 3(2):89-99. doi:10.1177/2042098611435911, http://www.ncbi.nlm.nih.gov.proxy.library.uu.nl/pmc/articles/PMC4110844/pdf/10.1177_204 2098611435911.pdf. Accessed 09 March 2016

World Health Organization (WHO) (n.d.) International classification of primary care, 2nd edn. (ICPC-2). http://www.who.int.proxy.library.uu.nl/classifications/icd/adaptations/icpc2/en/. Accessed 29 February 2016 
Schweikardt, C., Verheij, R.A., Donker, G.A., Coppieters, Y. The historical development of the Dutch Sentinel General Practice Network from a paper based into a digital primary care monitoring system. Journal of Public Health: 2016, 24(6), 545-562

\section{TABLES}

Table 1 Timeline: development of the Sentinel GP Network

\begin{tabular}{|c|c|c|c|}
\hline Year & Context & Sentinel GP Network & $\begin{array}{c}\text { Netherlands Information } \\
\text { Network of General } \\
\text { Practice (LINH) } \\
\end{array}$ \\
\hline 1965 & Foundation of the NHI & & \\
\hline 1966 & $\begin{array}{l}\text { The NHI director } \\
\text { becomes professor of } \\
\text { general practice at } \\
\text { Utrecht University (Van } \\
\text { Es 2006, pp. 70-71) }\end{array}$ & & \\
\hline 1970 & & $\begin{array}{l}\text { Foundation of the Sentinel GP } \\
\text { Network, NHI director } \\
\text { chairperson of the programme } \\
\text { committee (Programme } \\
\text { Committee Sentinel Practices } \\
1971, \text { p. } 10 \text { ) }\end{array}$ & \\
\hline 1971 & $\begin{array}{l}\text { Management of the NHI } \\
\text { separated from staff of } \\
\text { Utrecht University, new } \\
\text { NHI directors (Van Es } \\
\text { 2006, p. 128) }\end{array}$ & & \\
\hline 1972 & & $\begin{array}{l}\text { New NHI director chairperson } \\
\text { of the programme committee } \\
\text { (Programme Committee } \\
\text { Sentinel Practices } 1973, \text { p. } 7 \text { ) }\end{array}$ & \\
\hline 1985 & $\begin{array}{l}\text { Establishment of NIVEL } \\
\text { as successor of NHI }\end{array}$ & & \\
\hline $1987 / 1988$ & $\begin{array}{l}\text { First National Survey of } \\
\text { Morbidity and } \\
\text { Interventions in General } \\
\text { Practice }\end{array}$ & & \\
\hline 1991 & & & $\begin{array}{l}\begin{array}{l}\text { Foundation of LINH } \\
\text { (NIVEL/WOK) }\end{array} \\
\end{array}$ \\
\hline 1994 & & $\begin{array}{l}\text { Uncertain future of the } \\
\text { network made public during } \\
\text { annual meeting with GPs } \\
\text { (Bartelds 1995, p. 4) }\end{array}$ & \\
\hline 1996 & & & $\begin{array}{l}\text { LINH ends project status, } \\
\text { declared fully operational } \\
\text { and collecting referrals and } \\
\text { prescriptions with associated } \\
\text { morbidity }\end{array}$ \\
\hline
\end{tabular}


Schweikardt, C., Verheij, R.A., Donker, G.A., Coppieters, Y. The historical development of the Dutch Sentinel General Practice Network from a paper based into a digital primary care monitoring system. Journal of Public Health: 2016, 24(6), 545-562

\begin{tabular}{|c|c|c|c|}
\hline Year & Context & Sentinel GP Network & $\begin{array}{c}\text { Netherlands Information } \\
\text { Network of General } \\
\text { Practice (LINH) }\end{array}$ \\
\hline $2000-$ & $\begin{array}{l}\text { Second National Survey } \\
\text { of Morbidity and } \\
\text { Interventions in General } \\
\text { Practice }\end{array}$ & & $\begin{array}{l}\text { LINH is the basis of data } \\
\text { collection for national survey } \\
\text { of morbidity and } \\
\text { interventions in general } \\
\text { practice (Schellevis et al. } \\
\text { 2004) }\end{array}$ \\
\hline 2002 & & $\begin{array}{l}\text { Ministry of Health demands } \\
\text { Sentinel GP Network } \\
\text { alignment towards LINH } \\
\text { (Bartelds 2003, p. 16) }\end{array}$ & $\begin{array}{l}\text { LINH transition towards } \\
\text { logging all morbidity } \\
\text { recorded in general practice } \\
\text { (Verheij et al. 2002) }\end{array}$ \\
\hline 2004 & & \multicolumn{2}{|c|}{$\begin{array}{l}\text { NIVEL proposal to Ministry of Health to integrate Sentinel } \\
\text { GP Network and LINH }\end{array}$} \\
\hline 2005 & & $\begin{array}{l}\text { Integration of Sentinel GP } \\
\text { Network and LINH starts }\end{array}$ & \\
\hline 2006 & & \multicolumn{2}{|c|}{$\begin{array}{l}\text { Integration of routine EHR data from the Sentinel GP } \\
\text { Network into LINH starts (Verheij et al. 2010, p. 14) }\end{array}$} \\
\hline 2009 & & $\begin{array}{l}\text { Routine data collection of } \\
\text { diagnoses computerized } \\
(\text { Schellevis } 2011, \text { p. } 5)\end{array}$ & \\
\hline 2014 & & \multicolumn{2}{|c|}{$\begin{array}{l}\text { Establishment of NIVEL Primary Care Database integrating } \\
\text { the Sentinel GP Network, the Netherlands Information } \\
\text { Network of General Practice, and several other primary care } \\
\text { databases }\end{array}$} \\
\hline 2015 & & \multicolumn{2}{|c|}{$\begin{array}{l}\text { All questionnaire data of sentinel general practices collected } \\
\text { electronically }\end{array}$} \\
\hline
\end{tabular}

NHI Nederlands Huisartsen Instituut (Netherlands Institute of General Practice), NIVEL Nederlands Instituut voor Onderzoek van de Eerstelijnsgezondheidszorg (Netherlands Institute for Primary Care Research), from 1995 onwards Nederlands Instituut voor Onderzoek van de Gezondheidszorg (Netherlands Institute for Health Services Research); WOK Werkgroep Onderzoek Kwaliteit (Quality Research Working Group), LINH Landelijk Informatie Netwerk Huisartsenzorg (Netherlands Information Network of General Practice), EHR Electronic Health Record. Sources: Sentinel GP Network annual reports, LINH project and annual reports, 2004 NIVEL proposal to Federal Government, NIVEL publications, NIVEL homepage Van Es $\underline{2006}$ 
Schweikardt, C., Verheij, R.A., Donker, G.A., Coppieters, Y. The historical development of the Dutch Sentinel General Practice Network from a paper based into a digital primary care monitoring system. Journal of Public Health: 2016, 24(6), 545-562

Table 2 Characteristics of the Dutch sentinel GP practices within NIVEL Primary Care Database

\begin{tabular}{|c|c|}
\hline Aspect & Characterisrics \\
\hline Reporting period & Weekly \\
\hline Routine data collection & $\begin{array}{l}\text { EHR data extraction (contacts, morbidity by ICPC codes, } \\
\text { referrals, prescriptions) }\end{array}$ \\
\hline $\begin{array}{l}\text { Supplementary data } \\
\text { collection } \\
\text { (questionnaires) }\end{array}$ & $\begin{array}{l}\text { Up to } 15 \text { specific research topics, observation } \\
\text { period } \geq 1 \text { year, annual decision on prolongation and new } \\
\text { topics }\end{array}$ \\
\hline Number of practices & 40 (2014) (Donker 2016, p. 16) \\
\hline Number of GPs & 58 (2014) (Donker 2016, p. 16) \\
\hline \begin{tabular}{|l} 
Population of the \\
Netherlands covered
\end{tabular} & $\begin{array}{l}0.7-1.2 \%(2014, \text { differences according to province } \\
\text { group) (Donker 2016, p. 19) }\end{array}$ \\
\hline Representativeness & $\begin{array}{l}\text { As representative as possible for the Dutch population } \\
\text { (including gender, age, regional distribution-north, } \\
\text { south, east, west- and population density; Donker 2016, } \\
\text { pp. 15-21) }\end{array}$ \\
\hline $\begin{array}{l}\text { Documentation and } \\
\text { publications }\end{array}$ & $\begin{array}{l}\text { Annual reports in Dutch and English (publications } \\
\text { available online from } w \text { ww.nivel.nl ); scientific } \\
\text { publications of research results are mentioned in the } \\
\text { annual reports }\end{array}$ \\
\hline Umbrella organization & NIVEL Primary Care Database (since 2014) \\
\hline
\end{tabular}

Sources: NIVEL (n.d.) NIVEL Zorgregistraties eerste lijn; Donker 2016 [annual report for 2014] 
Schweikardt, C., Verheij, R.A., Donker, G.A., Coppieters, Y. The historical development of the Dutch Sentinel General Practice Network from a paper based into a digital primary care monitoring system. Journal of Public Health: 2016, 24(6), 545-562

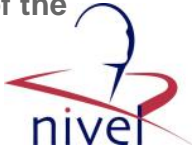

Table 3 General practice sentinel surveillance networks in six European countries with partly or completely computerised data collection or planned transition (for networks founded up to 1990, see also Van Casteren 1991)

\begin{tabular}{|c|c|c|c|c|}
\hline $\begin{array}{c}\text { Country/ } \\
\text { Region }\end{array}$ & \begin{tabular}{|c|} 
General Practice \\
Network
\end{tabular} & $\begin{array}{c}\text { Coordinating } \\
\text { institution }\end{array}$ & $\begin{array}{l}\text { Network } \\
\text { foundation/operatio } \\
\text { nal }\end{array}$ & Computerised data collection \\
\hline Belgium & $\begin{array}{l}\text { Réseau des } \\
\text { médecins vigies / } \\
\text { peilpraktijken }\end{array}$ & \begin{tabular}{|} 
Belgian Scientific \\
Institute of Public \\
Health (WIV-ISP)
\end{tabular} & $\begin{array}{l}1979 \text { (Van Casteren } \\
\underline{2009)}\end{array}$ & $\begin{array}{l}\text { Transition towards computerised data } \\
\text { collection planned for } 2016 / 2017 \text { in the } \\
\text { context of the Healthdata.be initiative, } \\
\text { providing data collection infrastructure } \\
\text { for Belgian health registries (Scientific } \\
\text { Institute of Public Health, } \\
\text { Healthdata (n.d.) Sur Healthdata.be): } \\
\text { extraction from EHR and/or manual } \\
\text { data entry (application on computer of } \\
\text { provider) (Scientific Institute of Public } \\
\text { Health, Healthdata (n.d.) Collecte des } \\
\text { données) }\end{array}$ \\
\hline $\begin{array}{l}\text { England/ } \\
\text { Wales } \\
\text { (United } \\
\text { Kingdom) }\end{array}$ & $\begin{array}{l}\text { Weekly Returns } \\
\text { Service, today } \\
\text { Royal College of } \\
\text { General } \\
\text { Practitioners } \\
\text { Research and } \\
\text { Surveillance Centre } \\
\text { (RCGP RSC) } \\
\text { (without Wales) } \\
\text { (Correa et al. 2016) }\end{array}$ & \begin{tabular}{|l} 
Research and \\
Surveillance \\
Centre of the \\
Royal College of \\
General \\
Practitioners
\end{tabular} & $\begin{array}{l}1967 \text { (Fleming and } \\
\text { Elliot 2006, p. 821) }\end{array}$ & $\begin{array}{l}\text { Transition towards computerised } \\
\text { reporting 1994-1998 (The Royal } \\
\text { College 2002). Since 2007 new } \\
\text { extraction routine introduced with } \\
\text { collection of patient-specific } \\
\text { longitudinal data (Fleming 2011), } 2011 \\
\text { used for influenza swabbing (Royal } \\
\text { College of General Practitioners, } \\
\text { Research \& Surveillance Centre (n.d.) } \\
\text { Weekly Returns Service Annual } \\
\text { Report 2011, pp. 9-12) }\end{array}$ \\
\hline France & $\begin{array}{l}\text { Réseau Sentinelles } \\
\text { (French General } \\
\text { Practitioners } \\
\text { Sentinel Network) }\end{array}$ & \begin{tabular}{|l} 
French National \\
Institute of Health \\
and Medical \\
Research \\
(Inserm)/Universit \\
y of Paris VI: \\
Pierre and Marie \\
Curie
\end{tabular} & \begin{tabular}{|}
1984 (Institut national \\
de la santé et de la \\
recherche médicale \\
(Inserm)/University \\
Paris VI Pierre et \\
Marie Curie (n.d.) \\
Réseau Sentinelles)
\end{tabular} & $\begin{array}{l}\text { Computerised at foundation: videotex } \\
\text { data entry application (Garnerin et al. } \\
\text { 1992, p. 35); web-based entry } \\
\text { preferred (1996), data entry via an } \\
\text { application on local GP computer } \\
\text { offered (2009) (Turbelin and Boëlle } \\
\underline{\text { 2010) }}\end{array}$ \\
\hline Portugal & Médicos Sentinela & \begin{tabular}{|l} 
National Health \\
Institute Doutor \\
Ricardo Jorge \\
(INSA)
\end{tabular} & $\begin{array}{l}1989 \text { (National Health } \\
\text { Institute Doutor } \\
\text { Ricardo Jorge } \\
\text { (INSA) (n.d.) Rede } \\
\text { Médicos Sentinela) }\end{array}$ & $\begin{array}{l}2002 \text { creation of online RIOS platform } \\
\text { (Redes de Informação e Observação } \\
\text { em Saúde) (platform also for other } \\
\text { networks) (National Health Institute } \\
\text { Doutor Ricardo Jorge (INSA) (2008) } \\
\text { Plataforma RIOS); 2003 pilot project } \\
\text { via internet (Deckers and Schellevis } \\
\text { 2004, Appendix B, p. 128); today } \\
\text { utilization of RIOS platform or data } \\
\text { collection on a specific paper form, } \\
\text { sent weekly by mail to the central } \\
\text { coordination office in Lisbon (Ana } \\
\text { Paula Rodrigues, personal } \\
\text { communication to the first author, } 21 \\
\text { February 2016) }\end{array}$ \\
\hline
\end{tabular}


Schweikardt, C., Verheij, R.A., Donker, G.A., Coppieters, Y. The historical development of the Dutch Sentinel General Practice Network from a paper based into a digital primary care monitoring system. Journal of Public Health: 2016, 24(6), 545-562

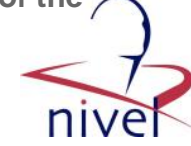

\begin{tabular}{|c|c|c|c|c|}
\hline $\begin{array}{c}\text { Country/ } \\
\text { Region }\end{array}$ & $\begin{array}{l}\text { General Practice } \\
\text { Network }\end{array}$ & $\begin{array}{l}\text { Coordinating } \\
\text { institution }\end{array}$ & $\begin{array}{l}\text { Network } \\
\text { foundation/operatio } \\
\text { nal }\end{array}$ & Computerised data collection \\
\hline $\begin{array}{l}\text { Castile and } \\
\text { Leon } \\
\text { (Spain) }\end{array}$ & $\begin{array}{l}\text { Red de Medicos } \\
\text { Centinela (since } \\
1991 \text { also } \\
\text { pediatricians), } \\
\text { since } 2006 \text { Red } \\
\text { Centinela Sanitaria } \\
\text { de Castilla y León } \\
\text { (also including } \\
\text { nursing staff) } \\
\text { (Junta de Castilla y } \\
\text { León, Consejería } \\
\text { de Sanidad (n.d.) } \\
\text { ¿Qué es?) }\end{array}$ & \begin{tabular}{|l} 
Regional \\
Government of \\
Castile and Leon, \\
Ministry of Health, \\
Directorate \\
General of Public \\
Health and \\
Research, \\
Development and \\
Innovation \\
(DGSPIDI) (Junta \\
de Castilla y \\
León, Consejería \\
de Sanidad \\
(2011) \\
Procedimientos, \\
p. 28)
\end{tabular} & $\begin{array}{l}1989 \text { (Vega Alonso et } \\
\text { al. } \underline{2006} \text {, p. 497) }\end{array}$ & $\begin{array}{l}\text { Influenza-tracking software on GP } \\
\text { computer (2015) (Saludadiario.es } \\
\text { (2015) En Castilla); data transfer from } \\
\text { the diabetes cohort via Medora } \\
\text { information system from January } 2015 \\
\text { onwards (Junta de Castilla y León, } \\
\text { Consejería de Sanidad (n.d.) Nueva } \\
\text { recogida) }\end{array}$ \\
\hline Switzerland & $\begin{array}{l}\text { Sentinella (GPs, } \\
\text { specialists in } \\
\text { internal medicine, } \\
\text { and pediatricians) }\end{array}$ & $\begin{array}{l}\text { Swiss Federal } \\
\text { Office of Public } \\
\text { Health, Division of } \\
\text { Epidemiology and } \\
\text { Infectious } \\
\text { Diseases }\end{array}$ & $\begin{array}{l}1986 \text { ( Swiss Federal } \\
\text { Office of Public } \\
\text { Health (n.d.) The } \\
\text { Swiss) }\end{array}$ & $\begin{array}{l}\text { Paper forms or online reporting on web } \\
\text { page (Schweizerische } \\
\text { Eidgenossenschaft, Bundesamt für } \\
\text { Gesundheit (n.d.) Das schweizerische } \\
\text { Sentinella-Meldesystem) }\end{array}$ \\
\hline
\end{tabular}

